\title{
Skill Bias Magnified: Intersectoral Linkages and White-Collar Labor Demand in U.S. Manufacturing
}

\author{
Nico Voigtländer* \\ UCLA and NBER \\ forthcoming: Review of Economics and Statistics
}

March 2013

\begin{abstract}
This paper presents a novel stylized fact and analyzes its contribution to the skill bias of technical change in U.S. manufacturing. The share of skilled labor embedded in intermediate inputs correlates strongly with the skill share employed in final production. This finding points towards an intersectoral technology-skill complementarity (ITSC). Together with input-output linkages, the observed complementarity delivers a multiplier that reinforces skill demand along the production chain. Reduced-form estimates suggest that the effect is quantitatively important, explaining about as much skill upgrading as outsourcing. Empirical evidence suggests that one channel through which this complementarity works is product innovation. I also analyze the importance of different drivers of skill upgrading over time. While foreign outsourcing and IT capital is associated with skill demand particularly strongly from the 1980s onwards (a period of rapidly increasing skill premia), R\&D contributed stably throughout the period 1958-2005. The same is true for ITSC, which augmented within-sector skill bias in a stable fashion throughout the last 5 decades.
\end{abstract}

JEL: J24, J31, O14, O15, O33, C67

Keywords: U.S. Income Inequality, Skill-Biased Technical Change, Intermediate Linkages, InputOutput, Complementarity

*UCLA Anderson School of Management, 110 Westwood Plaza, Los Angeles, CA 90095; nico.v@ anderson.ucla.edu. I thank three anonymous referees, as well as Daron Acemoglu, Fernando Broner, Paco Buera, Francesco Caselli, Rob Feenstra, Gino Gancia, Yuriy Gorodnichenko, Pierre-Olivier Gourinchas, Chad Jones, Lawrence Katz, Alexander Ludwig, Lee Ohanian, Giovanni Peri, Torsten Persson, David Romer, Jaume Ventura, Fabrizio Zilibotti, and seminar participants at UC Berkeley, CEMFI Madrid, Federal Reserve Board, IIES Stockholm, the NBER Summer Institute, Northwestern University, UC Davis, UCLA, UCSC, and Universitat Pompeu Fabra for helpful comments. I am indebted to Paula Bustos, Antonio Ciccone, and Joachim Voth for invaluable discussions. Nathan Nunn kindly shared his data on product differentiation. 


\section{Introduction}

As the supply of skilled workers has risen, so has the skill premium. A wealth of studies following Katz and Murphy (1992) documents a substantial increase in the demand for skilled labor over the last decades. Several channels have been proposed to explain this observation; most prominently, international trade and information technology. Together, these account for less than one half of the observed rise in skill demand in the U.S., leaving much to be explained. When quantifying contributions to rising skill demand, the literature has focused on skill-biased technical change (SBTC) - a shift in production technologies that favors skilled labor. Empirical studies have investigated SBTC at the worker-, firm-, and sector-level. Linkages across sectors have been ignored so far, despite the fact that more than half of a final product's value is embedded in intermediates.

This paper shows that skill upgrading in one sector goes hand-in-hand with increasing skill demand in many other sectors, because of linkages that operate through the use of intermediate products. I construct a measure of input-embedded skills, matching input-output (I-O) tables with workforce data for detailed U.S. manufacturing sectors over the period 1958 to 2005. Input skill intensity is defined as the weighted average share of white-collar workers employed in the production of a sector's intermediate inputs. ${ }^{1}$ Figure 1 presents a novel stylized fact: A strong positive correlation between input skill intensity and skills employed in final production. ${ }^{2}$ I argue that this finding implies an intersectoral technology-skill complementarity (ITSC): Skills used in intermediate production are complementary to skills required in the further processing of intermediates or their integration into redesigned final products. ITSC goes beyond the wellknown within-sector complementarity between skills and technology. In the empirical framework presented here, inputs from upstream sectors are not only 'intermediate' in the standard semi-manufactured sense, but also 'intermediaries' that transmit skill requirements across industries. This leads to a multiplier effect, which augments any given within-sector SBTC to a larger aggregate impact on skill demand. To gauge the magnitude of the effect, I introduce ITSC in the standard SBTC framework and estimate a reduced form. The results suggest that ITSC is quantitatively important, with conservative parameter values explaining 5$15 \%$ of the observed skill upgrading in U.S. manufacturing. This is the same order of magnitude as Feenstra and Hanson (1999) find for outsourcing.

\section{[Insert Figure 1 here]}

The empirical analysis in this paper is based on U.S. input-output data, paired with workforce characteristics from the NBER Manufacturing Industries Database at the detailed 4-digit SIC level. To these variables I add a large number of controls that were previously proposed in the wage inequality literature:

\footnotetext{
${ }^{1}$ White-collar (or non-production) workers - including personnel engaged in supervision, installation and servicing, professional, technological, and administrative - have been widely used to proxy for skilled labor. See in particular Berman, Bound, and Griliches (1994).

${ }^{2}$ The figure presents cross-sectional observations in the I-O benchmark year 1992. The correlation is very similar for any other benchmark year (5-year intervals) between 1967 and 2002.
} 
Capital equipment, shares of computer and high-tech capital, R\&D intensity, and outsourcing. ${ }^{3}$ The baseline analysis uses annual data and finds that the correlation between input skill intensity and skills in final production is stable over time and robust to the inclusion of the various controls and fixed effects. I also exclude inputs from broadly similar industries in the calculation of input skill intensity in order to address the concern that common trends at the aggregate industry level drive the observed correlation. In a similar vain, excluding electronic computer parts from intermediate inputs does not change my findings. In addition, my results hold when restricting the analysis to I-O benchmark years - 5-year intervals between 1967 and 2002.

The sample covers two periods. First, one of a relatively constant skill premium between the 1950s and 70s; second, a period of rapidly rising wage inequality, throughout the 1980s, 90s, and early 2000s (c.f. Appendix A.1, and Goldin and Katz, 2007, 2009). Interestingly, the magnitude of ITSC does not change between the two periods. The same holds for the contribution of R\&D intensity to skill upgrading (defined as a rise in skilled labor's share in employment and payroll). On the other hand, IT capital and outsourcing have become more important determinants of skill demand in the second period.

The paper examines one potential channel through which ITSC works: Skill-specific spillovers via product innovation. Skilled workers are not merely more productive, but are also good innovators, adapt better to technological change, and speed the process of technological diffusion (Nelson and Phelps, 1966; Bartel and Lichtenberg, 1987; Goldin and Katz, 1998; Doms, Dunne, and Troske, 1997). Because of this, an upstream supplier that employs highly educated workers will turn out innovative intermediates. These upstream product improvements induce innovation at the downstream level, which in turn increases downstream skill demand. ${ }^{4}$ Equally, a cutting-edge downstream firm demands innovative intermediate inputs. To supply these, upstream producers need highly skilled workers. Thus, whether innovation originates upstream or downstream is not crucial for my complementarity argument. One example for the product innovation channel is the invention and improvement of the transistor, which affected skill demand within and outside its sector of origin, the electronic components industry. Within this industry, the transistor enabled the production of more refined electronic parts, engineered by highly skilled workers. These innovative electronic components eventually became fundamental intermediate inputs for a large variety of other sectors, including computers, communication equipment, and controlling devices, where their integration went hand-in-hand with skill upgrading.

While the paper does not offer a direct proof that ITSC works through product innovation, I provide evidence that is consistent with this claim. The argument is based on the relationship between product innovation and differentiation. Differentiated goods can be refined more readily than homogeneous ones. For example, the presence of engineers contributes to the continuous improvement of electronic components. On the other hand, crude petroleum does not change, whether it is pumped out of the ground by laborers or university graduates. Following this argument, differentiated inputs are more susceptive to 'skill embedding' - their product characteristics reflect the skill intensity, or complexity, of the underlying production

\footnotetext{
${ }^{3}$ It is important to note that by construction, input-output linkages do not include investment goods. Thus, ITSC is strictly separated from capital-skill complementarity in my analysis.

${ }^{4}$ As Scherer (1982) for the United States and Pavitt (1984) for Great Britain show, product innovation in upstream sectors serves to improve productivity and quality of output in the buying industries.
} 
process. In contrast, innovations in the production of homogeneous inputs improve processes rather than products, and thus have little effect on downstream skill demand. ${ }^{5}$ Combining Rauch's (1999) classification of product differentiation with input-output tables, I construct a measure of input differentiation. I demonstrate that ITSC is increasing in the degree of input differentiation, and is close to zero for sectors that use mainly homogeneous inputs. In other words, intersectoral skill complementarities are strong when differentiated intermediates like electronic components form the link. However, when linkages work through homogeneous goods like crude oil, input skill intensity does not matter for skill shares in final production.

Finally, the paper sheds light on the quantitative importance of ITSC. I provide a simple extension of the standard SBTC framework with a CES production function, allowing upstream skill bias to affect the relative productivity of skilled workers in downstream industries. To measure upstream skill bias, I apply Caselli and Coleman's (2006) labor efficiency-based methodology at the sectoral level. I then estimate the model in a reduced form, where skill demand depends on within-sector skill bias as well as upstream skill bias. This allows me to evaluate the magnitude of the multiplier effect. On average, the estimates imply that ITSC augments any given within-sector skill demand by approximately one third. Since the previously identified within-sector drivers account for about $50 \%$ of skill upgrading, this suggests that ITSC delivers another $17 \%{ }^{6}$

This paper adds a novel angle to a large body of studies that seek to explain the remarkable increase in wage inequality in the United States starting in the 1960s. ${ }^{7}$ Existing work can explain some of the rising inequality, but falls short of accounting for all of it. The first prominent channel is trade and its effect on international patterns of specialization (e.g., Leamer, 1996; Wood, 1998). The between-component of trade - relocating production of low-skill-intensive industries to low-skill abundant countries - contributes little to the observed skill upgrading (Berman et al., 1994; Autor, Katz, and Krueger, 1998). Within-industry effects appear to be more important. To explain this observation, Feenstra and Hanson (1999) suggest outsourcing of low-skill intensive activities within firms or sectors. Their measure explains up to $15 \%$ of relative wage increases in U.S. manufacturing. ${ }^{8}$

The second prominent channel is skill-biased technical change. Numerous studies conceptualize SBTC as a complementarity between capital (or technology) and skills, where computer-based information technologies (IT) play a central, although disputed role (DiNardo and Pischke, 1997; Card and DiNardo, 2002; Autor, Levy, and Murnane, 2003). So far, the empirical SBTC literature has treated technology-skill com-

\footnotetext{
${ }^{5}$ I provide evidence for this assertion, combining data on sectoral product and process innovation from Scherer (1982) with Rauch's (1999) classification of product differentiation. The constructed cross-section shows that product innovation is more pronounced in sectors that produce differentiated goods. Thus, downstream users of differentiated intermediates purchase relatively more embedded product innovation.

${ }^{6}$ As discussed in section 3, these magnitudes have to be interpreted with caution due to possible endogeneity bias.

${ }^{7}$ For a recent review see Autor, Katz, and Kearney (2008), who also show that the growth of wage inequality is not an episodic event and provide new evidence showing that demand forces have played a key role in this process. Goldin and Katz (2009) provide a broad summary of U.S. income inequality, with particular emphasis on skill supply via education. Skill upgrading is also observed in other OECD countries (Machin and van Reenen, 1998; Berman, Bound, and Machin, 1998) as well as in developing countries (Pavcnik, 2003; Zhu, 2005). Acemoglu (1998, 2002a, 2007) provides a theoretical framework for factor-biased technological change.

${ }^{8}$ Crinò (2010) shows that offshoring also raises white-collar labor demand in the U.S. service sector.
} 
plementarities as a phenomenon within specific industries, within firms, and at the worker level. ${ }^{9}$ Computers and other high-tech capital have been shown to contribute about one third to the increase in white-collar labor demand in manufacturing (Feenstra and Hanson, 1999; Autor et al., 1998, 2003). ${ }^{10}$ Thus, the two most prominent (and previously quantified) drivers of skill upgrading - trade and IT - explain only about half of the overall magnitude.

There are other channels whose contribution to rising skill demand is more controversial or harder to pin down. I briefly discuss three prominent examples. First, Krusell, Ohanian, Ríus-Rull, and Violante (2000) provide a framework to quantify Griliches' (1969) influential hypothesis of a capital-skill complementarity. Krusell et al. find that observed changes in (quality-adjusted) capital inputs alone can explain most of the variation in the aggregate U.S. skill premium between the 1960s and early 90s. However, this finding has proved controversial; Acemoglu (2002b) shows that the result disappears upon the inclusion of a linear time trend. I do not take a stand on either of these positions and instead control for sector-level capital equipment to let the data speak for themselves. Second, R\&D is another potential driver of SBTC. However, while several studies document significantly positive coefficients of R\&D intensity (Machin and van Reenen, 1998; Autor et al., 1998), the variable itself changes relatively little over time so that its contribution to skill upgrading in manufacturing is probably limited. Finally, Card and DiNardo (2002) argue that rising wage inequality throughout the 1980s was merely an "episodic" event, driven mainly by declining real minimum wages. Autor et al. (2008) revise these claims, showing that rising inequality was largely driven by the upper part of the wage distribution, so that minimum wages cannot serve as an explanation.

The results reviewed above, and the ones presented in this paper, refer to a two-sector setup with whitecollar and blue-collar workers. Recently, several contributions have shown that this classification into two skill groups may be over-simplified. The U.S. and other developed countries have witnessed a polarization of labor demand; the middle-skilled group has been negatively affected by the automation of routine tasks (c.f. Autor et al., 2003; Goos and Manning, 2007; Autor et al., 2008; Acemoglu and Autor, 2011). Nevertheless, for a first pass at identifying intersectoral skill complementarities, it is sufficient to focus on two skill categories. This also has the advantage that consistent data are available for a long horizon in U.S. manufacturing. In addition, the trends in skill demand in manufacturing are representative of those in the U.S. economy overall (see Appendix A.1). Thus, many of the findings documented in this paper are probably generalizable to other sectors.

\footnotetext{
${ }^{9}$ For industries, Berman et al. (1994) find that the rate of skill upgrading within U.S. manufacturing is strongly correlated with IT investment and R\&D; IT accounts for much of the demand shift towards skilled workers over the 1980s. This effect has been greater in more IT-intensive industries (Autor et al., 1998). Autor et al. (2003) argue that computer capital substitutes for 'routine tasks' while it complements more complex 'nonroutine' tasks performed by skilled workers. At the firm and plant level, Levy and Murnane (1996), Doms et al. (1997), and Bresnahan, Brynjolfsson, and Hitt (2002) use broad measures of technological progress and provide evidence for skill-favoring demand shifts. Finally, at the worker level, Krueger (1993) and Autor et al. (1998) document a strong positive correlation between wages and computer use. Epifani and Gancia (2006) point out scale increases as an additional channel for skill bias. See Bound and Johnson (1992) and Autor et al. (2008) for an assessment of alternative explanations for wage inequality. Katz and Autor (1999) and Sanders and ter Weel (2000) summarize the literature at the three levels of aggregation.

${ }^{10}$ These estimates are to be interpreted with caution, as they take correlation coefficients as causal effects. Autor et al. (2003) investigate computer-induced task shifts in all sectors of the U.S. economy. Their approach can explain up to sixty percent of the relative demand shift favoring college labor; half of this impact is due to task changes within nominally identical occupations. The remaining thirty percent between occupations are similar to Feenstra and Hanson's finding.
} 
There is an ample literature on input-output linkages, starting with the pioneering work of Leontief (1936) and Hirschman (1958). Intermediate inputs account for a substantial share of overall costs - about $50 \%$ according to U.S. input-output tables. The remaining costs include employee compensation (about $30 \%$ ) and payments to capital (about 16\%). ${ }^{11}$ Studies of capital-skill complementarity therefore focus on a relatively small component of the final product's value. The empirical approach in this paper profits from the fact that by construction, intermediate linkages do not include investment (capital) goods. Thus, ITSC is strictly separated from the capital-skill complementarity literature.

Several studies have focused on the role of input-output multipliers in economic development. Ciccone (2002) shows that small increasing returns at the firm level can translate into large effects on aggregate income when industrialization goes hand-in-hand with the adoption of intermediate-input intensive technologies. Jones (2011) adds the role of input complementarity. Multipliers have also been used to explain the growth in the trade share of output, or the cyclical behavior of aggregate productivity. ${ }^{12}$ However, this paper is the first to investigate the role of intersectoral complementarities for skill upgrading.

The rest of the paper is organized as follows. Section 2 describes the data and explains the construction of a novel variable - input skill intensity. Section 3 reports empirical result. It first documents intersectoral technology-skill complementarity and confirms its robustness. The section then investigates one channel through which ITSC works, and finally examines the quantitative importance of ITSC. Section 4 concludes.

\section{Data}

This section describes the data that I use to construct input-skill intensity and control variables. Data on worker characteristics, wages, value of shipment, and real capital (equipment and structures) at the 4-digit SIC level are from the NBER-CES Manufacturing Industry Database. These data are collected from various years of the Annual Survey of Manufactures (ASM), and have been widely used to investigate the determinants of rising skill demand in the U.S. ${ }^{13}$ This (recently updated) database covers the period 1958-2005. It classifies employment in two broad categories: Production and non-production workers. The former are 'workers engaged in fabricating, processing, assembling, inspecting, and other manufacturing, while the latter are 'personnel, including those engaged in supervision, installation and servicing of own product, sales, delivery, professional, technological, administrative, etc.' As noted by Berman et al. (1994), the production/non-production classification closely mirrors the distinction between blue- and white-collar occupations from the Current Population Survey, which in turn closely reflects educational levels as high school vs. college. In the following, I refer to non-production (white-collar) workers as high-skilled labor

\footnotetext{
${ }^{11}$ These two, together with the minor component 'Indirect business tax and nontax liability' make up value added. These percentage values are derived from the 1992 U.S. input-output table from the Bureau of Economic Analysis. The numbers are very similar in other benchmark years.

${ }^{12} \mathrm{Yi}$ (2003) shows that small decreases in tariff barriers multiply up to large trade increases when intermediates are traded several times during the production process. Basu (1995) argues that intermediate goods act as a multiplier for price stickiness, augmenting little firm-level rigidity to a large economy-wide price inflexibility.

${ }^{13}$ Examples include Berman et al. (1994), Autor et al. (1998), and Feenstra and Hanson (1999). See Bartelsman and Grey (1996) for a documentation of these data.
} 
$H$ and to production (blue-collar) workers as low-skilled labor $L$.

The Bureau of Economic Analysis' (BEA) Input-Output Use Tables specify expenditures of each industry $i$ for intermediate inputs purchased from industry $j$. The BEA provides U.S. input-output (I-O) data at the 4-digit SIC level in 5-year periods (benchmark years) between 1967 and 1992. For some sectors, the level of aggregation or coverage changes over time. I account for this by aggregating sectors, and match the resulting I-O panel to the ASM's 1987 SIC classification. ${ }^{14}$ This aggregation yields 358 consistent manufacturing industries. In 1997, the BEA changed the I-O classification from SIC to NAICS. A correspondence is provided by the Census Bureau, but the match is imperfect for many sectors at the 4-digit level. In order to extend my sample to the 1997 and 2002 I-O benchmark tables, I apply the following strategy: (i) if several NAICS sectors match a single SIC sector, the former are aggregated; (ii) if one NAICS sector is split into several SIC sectors, industry-commodity specific shares from the 1992 I-O table are used to divide NAICS into the corresponding SIC components. ${ }^{15}$ Following this approach, I derive a coherent set of 358 sectors for all benchmark years between 1967 and 2002.

For each industry, the ASM provides annual data on production and non-production employment and wage payments, the value of shipments with the corresponding deflator $(1987=1)$, and real capital equipment. From the BEA I-O data, I derive the purchases of industry $i$ from sector $j$ in year $t, X_{i j t}$, in 5-year intervals over the period 1967-2002.

\section{Constructing input skill intensity}

To construct input skill intensity $\sigma_{i t}$, I first obtain intermediate input shares from the I-O expenditure data $X_{i j t}$. Let $X_{i t}=\sum_{j \neq i} X_{i j t}$ represent total (nominal) expenditures for manufacturing inputs purchased by industry $i$ outside the same industry in period $t$. The time-varying intermediate input shares are then given by $a_{i j t}=X_{i j t} / X_{i t}$. These are broadly stable over time. Spearman's rank correlation coefficients for $a_{i j t}$ are highly significant and range between .34 (for $a_{i j}^{1967}, a_{i j}^{2002}$ ) and .93 (for $a_{i j}^{1982}, a_{i j}^{1987}$ ). The same is true for pairwise correlation coefficients, ranging between .59 and .93 . Fluctuations over the eight benchmark years appear to be mainly noise. ${ }^{16}$ I use average input shares $\bar{a}_{i j}=\frac{1}{8} \sum_{t=67}^{02} a_{i j t}$ between 1967 and 2002 as a baseline. ${ }^{17}$ Input skill intensity is then defined as

$$
\sigma_{i t}=\sum_{j \neq i} \bar{a}_{i j} h_{j t}
$$

\footnotetext{
${ }^{14}$ For example, paper mills (SIC 2621) and paperboard mills (SIC 2631) are available separately in the I-O data until 1982, but aggregated from 1987 on. I treat these data as one sector, 'paper and paperboard mills' over the full sample period. Detailed sector correspondences are available upon request.

${ }^{15}$ The original NAICS-SIC correspondence is available at http://www.census.gov/epcd/www/naicstab.htm, and the extended correspondence including industry-commodity specific weights is available from the author.

${ }^{16}$ For example, in 1967 'Paperboard containers and boxes' accounted for 3.4\% of the manufacturing inputs in the 'Chocolate and cacao products' sector. This number almost quadrupled 5 years later (13.0\%), then stabilizing at about 6\% until 1992, and finally jumping to $10 \%$ in 1997 and 2002 . There is no reason to believe that the changing proportion reflects physical input shares. Measurement error as well as fluctuations in relative input prices, appear to be reasonable explanations.

${ }^{17}$ Constant nominal input shares correspond to a Cobb-Douglas technology. In Appendix B.2, I also use shipment deflators to derive constant price-adjusted input shares, which is closer to a Leontief technology. My results are very similar in this alternative setup. Both cases would be strong assumptions if nominal or real input shares shifted systematically towards more (or less) skill intensive industries. However, this is not the case, as I show in section 3.3.
} 
where $h_{j t} \equiv H_{j t} /\left(H_{j t}+L_{j t}\right)$ denotes the share of white-collar workers employed in the production of input $j$. As an alternative measure, I calculate $\sigma_{i t}^{w}$, using wage-bill instead of employment shares: $h_{j t}^{w} \equiv w_{H, j t} H_{j t} /\left(w_{H, j t} H_{j t}+w_{L, j t} L_{j t}\right)$, where $w_{H, j t}$ and $w_{L, j t}$ denote sector-specific white- and bluecollar wages, respectively. For both measures $\sigma_{i t}$ and $\sigma_{i t}^{w}$, I exclude inputs purchased within the same sector $(j=i)$. This avoids that skilled workers employed in sector $i$ itself enter its measure of input-embedded skills, which would bias my results. Using average input shares $\bar{a}_{i j}$ allows me to calculate $\sigma_{i t}\left(\sigma_{i t}^{w}\right)$ for all years where $h_{j t}\left(h_{j t}^{w}\right)$ is available from the ASM, that is, for 1958-2005. In the main analysis, I use the obtained annual data. All results hold when restricting the analysis to benchmark years in 5-year intervals between 1967 and 2002, as shown below.

A potential concern arises because inputs $X_{i j t}$ (and thus input shares $a_{i j t}$ ) contain imports from abroad, while the corresponding skill shares $h_{j t}$ are measured in U.S. sectors. ${ }^{18}$ However, the resulting measurement error of $\sigma_{i t}$ is likely to be minor, in particular prior to the 1990s, when the share of U.S. imports in non-energy intermediates was below 15\% (see the calculation of outsourcing variables in Appendix A.4). Moreover, most U.S. imports of intermediates in this period were sourced from other OECD countries with similar skill intensities. I show below that my results are identical for the pre-1980s subsample.

By construction, $\sigma_{i t} \in[0,1]$ is the weighted average share of white-collar workers involved in the production of sector $i$ 's intermediate manufacturing inputs. A more conservative measure of input skill intensity is obtained by excluding those inputs that are purchased within the same two-digit SIC industry. I implement this idea by restricting the four-digit industry subscripts $i$ and $j$ in (1) to be outside the same two-digit SIC industry. The resulting measure is labeled $\sigma_{i t}^{2 \mathrm{~d}}$. It addresses the concern that skill upgrading may happen simultaneously in similar industries, which would imply a spurious correlation of input and final production skill intensities when similar sectors buy each other's inputs. In addition, I calculate $\sigma_{i t}^{\text {nc }}$, excluding all electronic computing parts purchased as intermediate inputs. ${ }^{19}$ This variation of input skill intensity is particularly conservative in treating SBTC driven by computerization (cf. Autor et al., 1998, 2003). While computing-related intermediates do not include investment in computers as final products (e.g., computer equipment for use in offices), the two categories may be interrelated at the sectoral level. For example, high-tech sectors may adopt both computer equipment and computing-related intermediates more extensively than other sectors. The measure $\sigma_{i t}^{\text {nc }}$ addresses this issue by excluding computing-related intermediates. For both $\sigma_{i t}^{2 \mathrm{~d}}$ and $\sigma_{i t}^{\mathrm{nc}}$, the corresponding input shares $a_{i j t}^{2 \mathrm{~d}}$ and $a_{i j t}^{\mathrm{nc}}$ are calculated such that they sum to one, allowing a direct comparison with the estimated coefficients for $\sigma_{i t}$.

Input skill intensity $\sigma_{i t}$ is distributed between .06 and .57 with mean .25 and standard deviation .05 . Between 1958 and 2005, $\sigma_{i t}$ increased by $4.4 \%$ for an average industry. Across individual industries, this change varied widely - from a drop of $12.3 \%$ for Creamery Butter to a rise by $14.9 \%$ for communication equipment. ${ }^{20}$ Table 1 shows that sectors with declining $\sigma_{i t}$ over this period are mainly textile and food

\footnotetext{
${ }^{18}$ Unfortunately, the BEA provides import matrices only from 1997 on. But even these numbers are approximations and do not include the source country. Actual data on domestic vs. imported content of an industry's intermediate inputs are, for the most part, not available.

${ }^{19}$ In the 1987 SIC code, these comprise commodities 3571-2, 3575, and 3577.

${ }^{20}$ Sectoral levels of input skill intensity are not important for my empirical results - they are taken up by industry fixed effects in
} 
industries, such as 'Leather tanning \& finishing,' or 'Yarn mills.' These tend to use primary inputs, which in turn changed little or dropped in terms of white-collar employment shares. Industries that experienced the largest increase in input skill intensity include various electronic, computing, and communication equipment, as well as aircraft and space industries, all of which intensively use high-tech inputs that experienced innovation and skill-upgrading throughout the last decades.

\section{[Insert Table 1 here]}

\section{Additional control variables}

In the empirical analysis I include several variables that have been previously used to explain increasing demand for skilled labor. In the following I describe these variables briefly. The appendix provides more detail. Krusell et al. (2000) argue that the stock of capital equipment is complementary to skilled labor. To control for this capital-skill complementarity, I include real capital equipment per worker, $k^{\text {equip }}$. Data on research and development (R\&D) intensity are from the National Science Foundation (NSF). Following Autor et al. (1998), I use lagged R\&D intensity $\left(R \& D_{\text {lag }}\right)$ in the regressions. ${ }^{21} \mathrm{I}$ use data from the BEA to construct sectoral shares of high-technology capital $(H T / K)$ and office, computing \& accounting equipment $(O C A M / K){ }^{22}$ These data, as well as R\&D intensity, are available at roughly the 2-digit SIC level. Feenstra and Hanson (1999) document a significant impact of foreign outsourcing on relative wages. I calculate their broad $\left(O S^{\text {broad }}\right)$ and narrow $\left(O S^{\text {narr }}\right)$ measures of outsourcing for the years and sectors included in my sample. Feenstra and Hanson argue that the narrow measure - from within the same two-digit industry best captures the idea of outsourcing. For example, the import of steel by a U.S. automobile producer is normally not considered as outsourcing, while it is common to think of imported automobile parts by that company as outsourcing. Following this reasoning, I use $O S^{\text {narr }}$ as a baseline and include the difference between $O S^{\text {broad }}$ and $O S^{\text {narr }}$ as an additional regressor. Appendix A.4 provides additional information on the construction and sources of control variables.

Table 2 reports the pairwise correlations between two measures of input skill intensity $\left(\sigma_{i t}\right.$ and $\left.\sigma_{i t}^{2 \mathrm{~d}}\right)$ and the most prominent control variables. As in most of the following analyses, these correlations are obtained after controlling for industry and time fixed effects. The two measures of input skill intensity are highly correlated with one another, and are also correlated with control variables commonly used in the SBTC literature. Industries using skill-intensive intermediates tend to be capital and R\&D intensive, employ hightech capital, and outsource the production of their intermediates.

\section{[Insert Table 2 here]}

\footnotetext{
the regressions.

${ }^{21}$ Because industrial R\&D intensity tends to be persistent over time, working with lagged or contemporaneous R\&D makes almost no difference to the nature of my results.

${ }^{22}$ Both technology measures are widely used in studies of wage inequality. See, in particular, Autor et al. (1998) and Feenstra and Hanson (1999). The computer capital data are likely measured with substantial error, and are often not measured directly but inferred from employment data, assuming relationships between occupations and capital-type usage. See Becker, Haltiwanger, Jarmin, Klimek, and Wilson (2006) for a discussion. This implies an upward bias of computer capital's impact on skill upgrading, stacking the odds against finding an important contribution of input skill intensity.
} 


\section{Empirical Results}

In this section, I show that the novel stylized fact presented in the introduction is not an artifact: The correlation between input skill intensity and final production skill shares is robust to a variety of additional controls and specifications. I also provide suggestive evidence that is in line with ITSC working through product innovation. Finally, I examine the importance of intersectoral technology-skill complementarity for skill upgrading in U.S. manufacturing.

\subsection{Correlation of Skill Intensity across Sectors}

This section estimates different versions of the basic linear equation:

$$
h_{i t}=\alpha_{i}+\alpha_{t}+\beta \sigma_{i t}+\gamma Z_{i t}+\varepsilon_{i t}
$$

where $t$ indexes years between 1958 and 2005. Following the common empirical strategy in the SBTC literature (c.f. Autor et al., 1998; Machin and van Reenen, 1998), I use the high-skill labor share $h_{i t}$ (or the wage bill share $h_{i t}^{w}$ ) as dependent variable. Input skill intensity $\sigma_{i t}$ is calculated as in (1). ${ }^{23} Z_{i t}$ represents a set of variables that control for within-sector skill bias (note that $\gamma$ is a vector of coefficients), and $\alpha_{i}$ and $\alpha_{t}$ denote industry and time fixed effects, respectively. Finally, $\varepsilon_{i t}$ represents measurement error and unobserved drivers of the skilled labor share. My sample covers 358 sectors over 48 years. In the following, I drop time- and industry indexes for ease of exposition; unless mentioned otherwise, all variables are panel variables and implicity carry the index $i t$.

A first look at the data was provided above by Figure 1, plotting a cross-section of $h$ against $\sigma$, where both variables are calculated in 1992. The corresponding regression, including a constant term, yields a highly significant coefficient: $\beta=.957$, with a (robust) standard error of .101 . Column 1 in Table 3 reports a similar (although slightly larger) result for the pooled OLS regression using the annual panel. Two concerns arise. First, the observed correlation may be due to unobserved sectoral characteristics that drive both $h$ and $\sigma$. For example, industries that share input linkages may tend to locate close to one another, so that local labor supply may affect skill intensity in both upstream and downstream industries, making the observed correlation a spurious relationship. ${ }^{24}$ Second, in the pooled OLS, the correlation between $h$ and $\sigma$ may be spurious, driven by a general trend of skill upgrading. To address these concerns, I add sectoral and time fixed effects to the panel regressions in columns 2 and 3, respectively. The coefficients on input skill intensity remain highly significant and positive. While sector dummies capture unobserved static characteristics at the detailed (4-digit) industry level, common trends across I-O linked sectors and

\footnotetext{
${ }^{23}$ Because $\sigma_{i t}$ is based on $h_{j \neq i, t}$, the estimation in (2) offers a straightforward interpretation - it illustrates the correlation of skill-intensity in upstream and downstream production. In section 3.5, which examines the relative magnitude of ITSC, I provide more structure by deriving the estimation equation from a CES production function.

${ }^{24}$ Another story would be that the skill share in both final and the corresponding intermediate production is determined by technological history. Suppose that 'old' sectors are low-skill intensive, buying mainly 'old' inputs, while 'modern' sectors employ skilled workers and purchase 'modern' inputs. This would yield the observed correlation even in the absence of intersectoral technology-skill complementarities.
} 
endogeneity bias remain a concern. I address these in more detail below.

\section{[Insert Table 3 here]}

In column 4 of Table 3, I control for capital endowment as a determinant of skill upgrading. Krusell et al. (2000) argue that there is a strong complementarity between capital equipment and skilled labor in the aggregate U.S. economy. This finding is not reproduced at the detailed industry level - the coefficient on $k^{\text {equip }}$ has the wrong sign. ${ }^{25} \mathrm{I}$ also add the computer capital share $O C A M / K$ and the difference between high-tech and computer capital share $(H T / K-O C A M / K)$, which represents the fraction of capital services derived from various high-technology assets other than office, computing and accounting machinery. Both correlate positively with the proportion of skilled labor, and the latter is highly significant. This reflects the well-documented IT-skill complementarity. The coefficient of input skill intensity is robust to the inclusion of capital controls. The same holds when further controls are included: Column 5 adds the outsourcing variable $O S^{\text {narr }}$, together with the difference between the broad and narrow outsourcing measures $O S^{\text {broad }}-O S^{\text {narr }}$. The latter represents intermediate inputs from outside the two-digit purchasing industry that are sourced from abroad. In addition, column 5 controls for R\&D intensity. The sample size is now slightly smaller due to missing observations in the outsourcing measure. Lagged R\&D intensity as well as the outsourcing variables have a significantly positive correlation with skilled labor in final production, which confirms previous findings (Machin and van Reenen, 1998; Feenstra and Hanson, 1999).

Column 6 uses an alternative measure of input skill intensity, $\sigma^{2 \mathrm{~d}}$, excluding inputs purchased within the same 2-digit industries. This specification addresses the concern that common trends or technology shocks may drive skill upgrading in similar industries, biasing $\beta$ upwards when these industries are linked via input-output relationships. The more conservative measure comes along with a cost: $\sigma^{2 \mathrm{~d}}$ discards a substantial part of intersectoral linkages, since sectors purchase on average $35 \%$ of their inputs within the same 2-digit category. Therefore, $\sigma^{2 \mathrm{~d}}$ is a more noisy measure of input skill intensity and likely subject to attenuation bias. Nevertheless, the coefficient is only slightly smaller than in the previous specifications and still highly significant. Appendix B.1 shows that my results are also very similar when excluding computerrelated intermediate inputs or when using the wage-bill share of white collar workers to calculate input skill intensity.

How much of the variation in $h$ can input skill intensity explain? Table 3 reports two frequently used measures for the goodness of fit: One including the variation explained by sectoral fixed effects $\left(R^{2}\right)$, and the other assessing the model's fit after accounting for sectoral dummies ( $R^{2}$ within). The former is close to unity, beginning in column 2, i.e., once sector fixed effects are included. The latter implies that the regressions presented in Table 3 account for roughly half of the variation of $h$ within sectors over time. Changes in $R^{2}$-within can be interpreted as explanatory power of individual variables. I analyze the most conservative case, calculating $\triangle R^{2}$-within when adding $\sigma$ to the regression after all other controls and fixed

\footnotetext{
${ }^{25}$ This supports Acemoglu's (2002b) critical view of Krusell et al.'s results, which disappears when a linear time trend is included in the regressions. In fact, if I include only $k^{\text {equip }}$ and sectoral dummies as explanatory variables in (2), the coefficient on $k^{\text {equip }}$ is positive and highly significant. As soon as other controls or time dummies are included, the coefficient becomes insignificant or significantly negative.
} 
effects have been included. This implies that input skill intensity can account for about $3 \%$ of the variation in white-collar labor shares within sectors; when allowing for variation across sectors, $\sigma$ explains about $8 \%$ of the variation. ${ }^{26}$ However, these results should not be interpreted as the quantitative importance of ITSC, which is analyzed in section 3.5.

Finally, I implement two additional checks addressing the concern that common shocks to similar industries drive my results. Both are based on column 5 and are not reported in the table. First, I include year-specific dummies at the 2-digit industry level in addition to all controls and sector fixed effects. These absorb common industry shocks to skill demand, such that the coefficient $\beta$ only reflects the variation of detailed 4-digit sectors relative to the corresponding 2-digit industries. Even with this restriction, the coefficient remains significant and of similar magnitude, $\beta=.413$ (.198). Second, I use the 5-year lag of $\sigma$. The coefficient on $\sigma_{i, t-5}$ is highly significant, .383 (.115), with all other coefficients very similar to those reported in column 5. This finding mitigates the concern related to common shocks and simultaneity - to maintain it, one would have to argue that downstream skill demand reacts half a decade later than its upstream counterpart to the same shock.

\subsection{Periods of Stagnant and Rising Skill Premia}

My sample spans a period of a relatively constant manufacturing skill premium until the early 1980s and thereafter a period of rapid increases in $w_{H} / w_{L}$. Between 1958 and 1980, $w_{H} / w_{L}$ grew by $.05 \%$ on average, which almost tripled to .14\% between 1980 and 2005. The share of white-collar employment, however, rose at a roughly constant rate over the full sample period (.62 and .52 percent, respectively). With the skill premium and the share of skilled workers rising hand-in-hand, skill demand must have risen throughout the full period; and possibly at a faster pace from the 1980s onwards. ${ }^{27}$ This section allows all coefficients in (2) to differ between the two periods, by multiplying each variable with the indicator $I^{t \geq 1980}$ (which equals one from 1980 onward).

Table 4 presents the results. Once all control variables are included (from column 4 on), the correlation of input skill intensity and the skill share in final production does not change significantly between the two periods. This indicates that ITSC is a stable phenomenon. The coefficients of capital equipment does not differ significantly across the two periods, either, while R\&D intensity appears to be less important in the second half of the sample. The contrary is true for computer capital. OCAM/K becomes important only from 1980 onward, suggesting that computers contributed to the hike in the skill premium (c.f. Autor et al., 2003). The broader category, high-tech capital other than computers, gained less additional importance during the second period. Finally, the broad outsourcing measure correlates more strongly with $h$ after 1980, suggesting that offshoring, like computers, contributed to the acceleration of skill demand and thus to the spike in the wage premium after the 1980s.

\footnotetext{
${ }^{26}$ When $\sigma$ is excluded from column 5 , the $R^{2}$-within drops from 0.476 to 0.444 . In the absence of sector fixed effects (but with all other controls; not reported in the table), the adjusted $R^{2}$ drops from 0.484 to 0.407 when $\sigma$ is excluded.

${ }^{27}$ Goldin and Katz (2009) point out that for the U.S. economy as a whole, a slowdown in the growth of educational attainment since the 1980s is likely responsible for the rising post-1980 college wage premium. This skill supply effect appears to be less pronounced in manufacturing, where the growth of $h$ decelerated only slightly after 1980 .
} 


\section{[Insert Table 4 here]}

\subsection{Robustness of the Correlation}

So far, input skill intensity ( $\sigma$ and $\sigma^{2 \mathrm{~d}}$ ) was calculated based on constant input shares. In the following, I show that my findings are robust to using input skill intensity measures based on changing input shares. This requires to restrict the sample to years where benchmark I-O data are available: 5-year intervals between 1967 and 2002. Finally, I test the sensitivity and robustness of my estimates to alternative specifications and controls.

Input skill intensity with time-varying input shares

My baseline input skill intensity measures in (1) are derived from average input shares $\bar{a}_{i j}$. In the following, I use the time-varying $a_{i j}$ to construct an alternative input skill intensity measure, $S_{i t}=\sum_{j \neq i} a_{i j t} h_{j t}$. This variable can be decomposed into three parts. First, a skill component $\sigma_{i t}$, as defined in (1), representing constant input expenditure shares with changing skilled labor shares of suppliers. Second, an input-mix component $\tau_{i t}=\sum_{j \neq i} a_{i j t} \bar{h}_{j}$, reflecting varying input shares with constant skilled labor shares of suppliers. This variable grows over time if sector $i$ switches its input mix towards more skill intensive intermediates. Finally, a covariance component $\rho_{i t}=\sum_{j \neq i}\left(a_{i j t}-\bar{a}_{i j}\right)\left(h_{j t}-\bar{h}_{j}\right)-\sum_{j \neq i} \bar{a}_{i j} \bar{h}_{j}$, which grows if sector $i$ switches its input mix towards sectors whose skill intensity rises over time. ${ }^{28}$ Note that $S_{i t}=\sigma_{i t}+\tau_{i t}+\rho_{i t}$. Because time-varying input shares are only available for I-O benchmark years, I restrict the sample to quinquennial intervals between 1967 and 2002. Over this period, the skill component $\sigma_{i t}$ is by far the most important contributor to increases in $S_{i t}$. The weighted average of $S_{i t}$ increases from 22.2 to 27.7 percent. Of this $5.5 \%$ rise, $5.7 \%$ are due to $\sigma_{i t}, 0.7 \%$ to $\tau_{i t}$, and $-0.9 \%$ to $\rho_{i t}$. The latter means that on average, sectors lowered their expenditure share for intermediates whose skill intensity rose rapidly (although the magnitude of this shift is small).

Table 5 reports the estimation results of regression (2) with all variables in 5-year intervals between 1967 and 2002. The first two columns show that the coefficient of $\sigma_{i t}$ is very similar in magnitude compared with the annual regressions, despite the fact that the number of observations is substantially lower. Moreover, neither including the two variables $\tau_{i t}$ and $\rho_{i t}$, nor controlling for additional variables affects the significance of $\sigma_{i t}{ }^{29}$ The same is true for the more conservative measure $\sigma_{i t}^{2 \mathrm{~d}}$ in columns 3 and 4 .

\section{[Insert Table 5 here]}

The covariance components $\rho_{i t}$ and $\rho_{i t}^{2 \mathrm{~d}}$ are positive and significant in most specifications. Note that because $\rho_{i t}$ fell slightly over the sample period, this contributes negatively to $h_{i t}$. In other words, because industries lowered their expenditure shares for intermediates with rising skill intensity, the skill share in final production rose somewhat less rapidly than it would have with constant intermediate expenditure shares.

\footnotetext{
${ }^{28}$ The term $\sum_{j \neq i} \bar{a}_{i j} \bar{h}_{j}$ is a constant for each sector $i$ and does not influence estimation results in the presence of sectoral fixed effects.

${ }^{29}$ As was the case with annual data in Table 3, the coefficient of $\sigma_{i t}$ drops by about .3 when the full set of controls is included.
} 
Finally, the results do not indicate that a general switch towards more skill intensive intermediates drove skill demand in final production - the input mix components $\tau_{i t}$ and $\tau_{i t}^{2 \mathrm{~d}}$ are not robust. However, this finding is likely affected by the noise in the time-varying input shares. ${ }^{30}$ Similarly, I expect attenuation bias and therefore a smaller coefficient when using the composite skill intensity $S_{i t}$. Columns 5 and 6 show this result with and without control variables. Nevertheless, the coefficients on $S_{i t}$ are still highly significant.

\section{Alternative specifications and further controls}

Some controls used in the following are derived directly from I-O tables, and are thus only available for benchmark years. For consistency, I thus use the quinquennial sample for all alternative specifications. I run regression (2) in changes, include further controls, and restrict the sample to single years, analyzing cross-sections rather than a panel. I also show that my findings are robust to the inclusion of sector-specific time trends. Table 6 presents the first set of results.

\section{[Insert Table 6 here]}

The first column of Table 6 runs the baseline regression in changes, instead of including fixed effects. All variables are in 5-year differences. The corresponding coefficient on input skill intensity is very similar to the one obtained above in the annual sample, and is again highly significant. In column 2 , I return to estimating levels, including fixed effects and all previously used controls. Additionally, I control for a number of other variables that potentially drive skill demand. First, two measures of the 'complexity' of the production process: The variety of inputs used in production, measured as one minus the Herfindahl index of input concentration for each industry $\left(1-H_{i t}\right)$. This variable is used as a measure of a good's 'complexity' by Blanchard and Kremer (1997) to explain the decline of output when bargaining breaks down along the production chain. The other measure for production 'complexity' is an indicator function for the number of inputs, proposed by Nunn (2007). $I_{i t}^{n_{i t}>\bar{n}_{t}}$ equals one if the number of inputs $n_{i t}$ used in industry $i$ in year $t$ is greater than the median number of inputs used in all industries, $\bar{n}_{t}$. I derive both measures from the benchmark I-O tables for the quinquennial sample. Since more 'complex' production processes require more coordination, I expect these variables to have a positive impact on the demand for skilled labor. Second, I include the sector-specific skill premium, or relative wage $w_{H, i t} / w_{L, i t}$, to capture differences in cost and quality of skilled workers across sectors. ${ }^{31}$ Third, I control for production scale and productivity by including the real value of shipments, $\ln (Y)$, and total factor productivity, $\ln (T F P)$. Finally, the share of value added in total cost controls for the overall importance of labor and capital (as opposed to intermediate inputs) in production. Service-oriented sectors generally have a larger value added share, and also a higher proportion of white-collar labor.

\footnotetext{
${ }^{30}$ Less than $1 / 3$ of all relevant (i.e., non-zero) input shares have a time-trend that is significant at the $10 \%$ level. In an additional check not presented here, I calculate $\tau_{i t}$ and $\rho_{i t}$ using changing input shares whenever the time-trend is significant, and average shares otherwise. Under this method, $\tau_{i t}$ is significant at the $5 \%$ level when all controls are included, while the coefficient of $\sigma_{i t}$ remains unchanged.

${ }^{31}$ Because of its endogeneity with skill demand, this variable is usually not included in regressions where the dependent variable is the share of skilled workers. See Feenstra (2004, ch. 4) for a discussion.
} 
The inclusion of further control variables shown in column 2 of Table 6 changes neither the size nor the high statistical significance of the coefficient on input skill intensity. Most additional controls are insignificant. Neither of the two I-O based measures for production 'complexity' has a significant impact on skill demand. ${ }^{32}$ The relative wage of skilled workers is significant with the expected negative sign. Column 3 presents the regression with the non-production wage-bill share as dependent variable. This measure is frequently used as an alternative to the purely labor based measure, as it also captures skill upgrading within either occupational category (Berman et al., 1994). ${ }^{33}$ The wage-bill regression confirms magnitude and significance of the ITSC effect. Appendix B.1 provides additional robustness checks involving the wage-bill share of white collar workers.

In all panel regressions presented so far, I address the concern of inconsistent standard errors due to serially correlated observations by accounting for correlation within sectors across time (i.e., by clustering standard errors at the sector level). Bertrand, Duflo, and Mullainathan (2004) argue that this correction alone may not fully solve the problem and suggest collapsing the time series information into single periods as a further correction. ${ }^{34}$ Columns 4-6 of Table 6 implement this additional consistency check, presenting crosssectional regressions for the first and the last benchmark year based on SIC I-O data (1967 and 1992), as well as for the last year of the sample, which is based on a correspondence from NAICS to SIC (2002). Fixed effects cannot be used in this specification, raising the concern that unobserved characteristics, like similarity of sectors, drive the correlation between input skill intensity and the skilled labor share in final production. To alleviate this concern, I use $\sigma^{2 \mathrm{~d}}$ as the input skill intensity measure, excluding linkages within 2-digit industries. The corresponding coefficient is of the same magnitude as observed before, significant in 1967, and highly significant in 1992 and 2002. Most control variables also confirm the previous findings. Finally, production 'complexity,' measured by $I_{i}^{n_{i}>\bar{n}}$, correlates positively with skill demand and is statistically significant in the 1992 cross-section.

Table 7 reports further robustness checks. The first column shows results for unweighted regressions, while the second column restricts the sample to the 1967-92 benchmark years. This corresponds to the period for which a consistent I-O classification at the 4-digit SIC level is available. For the remaining benchmark years - 1997 and 2002 - input shares are based on a BEA correspondence between NAICS and SIC. Both columns 1 and 2 confirm my results. Finally, columns 3-5 include time trends at the 4-digit sector level in addition to fixed effects. This addresses the concern that the observed ITSC is driven by common trends in sectors that share input-output linkages. ${ }^{35}$ The coefficients on the three measures of input skill intensity $\left(\sigma, \sigma_{i}^{2 \mathrm{~d}}\right.$, and $\left.\sigma_{i}^{w}\right)$ drop only slightly. Altogether, the empirical results suggests that ITSC is a highly robust novel finding that is not driven by simultaneous skill upgrading in similar sectors.

\footnotetext{
${ }^{32}$ The two complexity measures vary little over time, and the inclusion of sector fixed effects eliminates much of their variation. In fact, when running the same regression without sector dummies, the coefficient of $I_{i}^{n_{i}>\bar{n}}$ is positive and significant.

${ }^{33}$ Fox and Smeets (2011) show that the wage bill explains as much productivity dispersion across firms as a wide array of human capital measures, using a matched employer-employee dataset from Denmark.

${ }^{34}$ Long time series (15 periods and more) are a major contributing factor to Bertrand et al.'s concern - this applies to my baseline analysis with annual data between 1958 and 2005. The quinquennial benchmark year panel, however, involves only 8 periods. Thus, the concern is likely of minor importance for this subsample, given that I am already controlling for serial correlation.

${ }^{35}$ In addition, the setup will capture different sector-specific trends in the relative quality of $H$ vs. $L$.
} 


\section{[Insert Table 7 here]}

\subsection{Product Innovation and Channel of ITSC}

This section examines one possible channel through which intersectoral technology-skill complementarity works. In the empirical framework analyzed above, upstream and downstream sectors are linked through intermediate products. Spillovers along intermediate linkages are thus a natural starting point to look for the ITSC channel. In the following, I suggest that product innovation is a potential way through which such spillovers may work: Skilled workers (or their ideas) shape intermediate products such that skills are needed in their further processing. The channel is thus product innovation, and whether or not it operates depends on the characteristics of the involved intermediates. For example, suppose that Exxon decides to boost productivity in oil extraction and hires a large number of engineers. More skills will shape the extraction process, but not the product - crude oil. Consequently, skill demand in a downstream refinery will be unaffected by Exxon's skill upgrading. On the other hand, trained engineers inventing ever better and smaller data storage devices enabled Apple to launch the iPad - a highly skill-intensive endeavor. ${ }^{36}$ Crude oil is a homogeneous product, while data storage devices are differentiated; my investigation of the ITSC channel is built around this classification. I provide suggestive evidence that ITSC is strong when highly differentiated intermediates form the link, while the relationship is insignificant for homogeneous intermediates. Before turning to the data, I briefly discuss the two separate concepts of linkages across sectors and innovation-skill complementarity within sectors. Joining them implies ITSC via product innovation.

\section{Intersectoral Linkages and Skill Complementarity}

Linkages across industries alone need not imply connected skill requirements. What makes the proposed point plausible is innovation-skill complementarity within sectors, combined with innovation spillovers across sectors, through input-output linkages. There is substantial evidence for technological linkages across sectors. Scherer (1982) and Pavitt (1984) use patent data to track the flow of innovation across sectors. Both confirm the overall prevalence of product innovation, which accounts for 73.8 percent of total R\&D outlays in the United States, and 75.3 percent in Great Britain. ${ }^{37}$ As Scherer (1982, p.227) emphasizes:

"If [a new product] is a producer good or intermediate sold externally, it serves to improve output/input relationships or the quality of output in the buying industries. With a new turbojet engine product, for example, the $R \& D$ is performed in the aircraft engine industry, but the productivity effect often shows up in lower energy consumption or faster, quieter, and more reliable operation of equipment used by the quite distinct airlines industry. [...] to assume that the productivity-enhancing effect occurs solely within the R\&D-performing industry [...] is more wrong than right, since three-fourths of all industrial R\&D is devoted to new or improved

\footnotetext{
${ }^{36}$ The story also works in the opposite direction. When Apple works on improvements for the next-generation iPad, it creates demand for more powerful memory devices and batteries. Both causal directions are compatible with the ITSC framework.

${ }^{37}$ In this context, product innovations are by definition used outside their sector of origin, i.e., they are passed to downstream sectors or consumers in the form of improved products. Scherer (1982) also provides evidence that most productivity benefits are realized by $R \& D$ using, rather than product $R \& D$-originating industries.
} 
products, as distinguished from processes."

There is ample evidence for innovation spillovers from upstream suppliers to downstream final producers, via intermediate linkages. The channel also operates in the opposite direction. For example, Blalock and Gertler (2008) document vertical spillovers in the case of foreign investment in Indonesia: Subsidiaries of multinational enterprises provide technological knowledge to their local intermediate suppliers in order to reduce prices and increase competition in upstream markets. ${ }^{38}$

Within sectors, innovation goes hand in hand with skilled labor. ${ }^{39}$ In addition, much of the innovative activity creates new products that are used as intermediates in other sectors. So far, these two facts have been treated separately in the literature. Combining them yields an intersectoral technology-skill complementarity. The interactions of innovation and skills run in both directions, and across sectors, reinforcing one another. Individually and collectively, innovations in sectors related through input-output linkages increase the relative demand for skilled labor $(h)$ as summarized below:

\section{Downstream Upstream}

$\begin{array}{ccc}\text { Product Innovation }_{i} & \Leftrightarrow & \text { Product }_{\text {Innovation }_{j}} \\ \uparrow & \text { I-O linkages } & \uparrow \\ h_{i} & & h_{j}\end{array}$

Closest in spirit to this interpretation of ITSC are the complementarity frameworks proposed by Milgrom and Roberts (1990) and Bresnahan et al. (2002), where the adoption of IT, work organization, product innovation, and skill upgrading reinforce each other within, but not across firms. ${ }^{40}$

\section{Empirical implementation: Product innovation and product differentiation}

To provide suggestive evidence for the product innovation channel, I follow a two-step process. First, I show that sectors producing differentiated products spend relatively more R\&D for product innovation, while producers of homogeneous goods concentrate on innovating their own processes. This suggests that differentiated products embody more innovation than homogeneous ones. Therefore, sectors using differentiated intermediates purchase relatively more embodied product innovation, which leads to the second step: If ITSC works through product innovation, I expect it to be stronger for sectors that use relatively more differentiated inputs. I provide evidence that is in line with this assertion. In addition, I show that input skill intensity raises the number of skilled workers, but does not affect the number of unskilled workers. This finding supports the innovation story, while speaking against automation as a driver of my results.

\footnotetext{
${ }^{38}$ For a theoretical framework see Rodríguez-Clare (1996). Keller (2004) and Koo (2005) summarize the literature on international and local technology spillovers.

${ }^{39}$ The same is true for a specific result of innovation: Product quality. As Verhoogen (2008) shows, producing high-quality goods requires skilled workers.

${ }^{40}$ Kugler and Verhoogen (2012) use a similar mechanism to explain the positive correlation between input prices, output prices, and firm size in a panel of Columbian firms. In their framework, input and output quality are complementary.
} 
As described in Appendix A.2, I derive sectoral shares of R\&D expenditures used for product innovation, $\pi_{i}^{\text {prod }}$, from Scherer's (1982) data, and match them to Rauch's (1999) data on product differentiation. This gives $\pi_{i}^{\text {prod }}$ together with the share of products classified as differentiated, $R_{i}^{\text {diff }}$, for 34 manufacturing industries. The median of $R_{i}^{\text {diff }}$ in this sample is .84. The 17 industries turning out goods with below-median product differentiation spend on average 53\% of R\&D for inventing new products (as opposed to processes), while this number is $80 \%$ for producers of above-median differentiated goods. After this preliminary observation, I turn to the simple cross-section regression $\pi_{i}^{\text {prod }}=\delta_{0}+\delta_{1} R_{i}^{\text {diff }}+\varepsilon_{i}$. The corresponding estimate is positive and highly significant: $\delta_{1}=.416$ with a robust standard error of .127 and $R^{2}$ of .27 .41 These findings suggest that differentiated products are more susceptive to product innovation, such that they are more readily reshaped by the innovative minds of skilled workers.

These results show that purchasers of differentiated inputs buy on average more innovation incorporated in their intermediates than users of homogeneous inputs. Therefore, input differentiation gives the degree to which skill-biased innovation can be 'embedded' in intermediates. I consequently expect stronger ITSC when input-output linkages involve more differentiated intermediates. The corresponding measure $\kappa_{i}$ (described in Appendix A.3) gives the weighted average degree of input differentiation. I thus expect a larger $\beta$ in regression (2) for sectors with larger $\kappa_{i}$. To obtain a first look at the data, I use $\kappa_{i}$ to define the indicator variable $I_{i}^{\kappa_{i}>\widetilde{\kappa}}$, which equals one for sectors with above-median input differentiation. I then use this variable to split $\sigma_{i t}$ into two components: $\sigma_{i t}^{A M}$ and $\sigma_{i t}^{B M}$ for above- and below-median $\kappa_{i}$, respectively. Note that $\sigma_{i t}^{A M}+\sigma_{i t}^{B M}=\sigma_{i t}$. Then I estimate the regression

$$
h_{i t}=\alpha_{i}+\alpha_{t}+I_{i}^{\kappa_{i}>\widetilde{\kappa}}+\beta^{A M} \sigma_{i t}^{A M}+\beta^{B M} \sigma_{i t}^{B M}+\gamma Z_{i t}+\varepsilon_{i t},
$$

where $I_{i}^{\kappa_{i}>\widetilde{\kappa}}$ captures the difference in the intercept for sectors with above-median input differentiation (which is identified if one of the sector-dummies $\alpha_{i}$ is dropped). Figure 2 illustrates the results in the form of partial scatter plots. The vertical axis shows the variation in the skilled labor share $h_{i t}$ to be explained by input skill intensity, after accounting for fixed effects and the previously used control variables.

\section{[Insert Figure 2 here]}

The left panel of Figure 2 shows the partial scatterplot for the full sample, where the corresponding coefficient from regression (2) is $\hat{\beta}=.52$. The plot also shows that the positive correlation between input skill intensity and final production skills is a broad phenomenon, not driven by outliers. The right panel repeats the exercise for estimates from regression (3), showing that ITSC is stronger for sectors that use more differentiated inputs. The corresponding coefficients are $\hat{\beta}^{A M}=.81(.15)$ and $\hat{\beta}^{B M}=.35(.11)$, whose difference is significant at the $1 \%$ level. ${ }^{42}$ In addition, sectors using more differentiated inputs are on

\footnotetext{
${ }^{41}$ The result is practically identical when using Rauch's (1999) conservative estimate to construct $R_{i}^{\text {diff }}$. Outliers are not an issue, and even excluding the 9 sectors that produce only differentiated products $\left(R_{i}^{\text {diff }}=1\right)$ leaves the remaining ones with a significantly positive $\delta_{1}$.

${ }^{42} \mathrm{~A}$ more detailed analysis, using quintiles of input differentiation $\kappa_{i}$, confirms this result: $\hat{\beta}$ increases with each quintile of $\kappa_{i}$ and is highly significant for all except the first one.
} 
average more skill intensive: The indicator variable $I_{i}^{\kappa_{i}>\widetilde{\kappa}}$ has a coefficient of .10 (.04). This is what one should expect, given that differentiated inputs incorporate more product innovation.

Next, I include interaction terms of explanatory variables with input differentiation $\kappa_{i}$, estimating the following extended equation: ${ }^{43}$

$$
h_{i t}=\alpha_{i}+\alpha_{t}+\beta_{1} \sigma_{i t}+\beta_{2} \kappa_{i} \times \sigma_{i t}+\gamma_{1} Z_{i t}+\gamma_{2} \kappa_{i} \times Z_{i t}+\varepsilon_{i t}
$$

Table 8 reports the results, using the two alternative measures for input skill intensity, $\sigma$ (baseline) and $\sigma^{2 \mathrm{~d}}$ (excluding inputs from the same 2-digit sectors). I begin with the annual sample (columns 1-3), and then show that the results are almost identical when using the quinquennial sample for benchmark years between 1967 and 2002 (columns 4-6). The interactions 'input differentiation' $\times$ 'input skill intensity' are positive and highly significant, suggesting that ITSC grows with the degree of input differentiation. Moreover, the coefficient on input skill intensity alone $\left(\beta_{1}\right)$ is small and insignificant in all specifications. This indicates that ITSC is not present for a (hypothetical) sector using only homogeneous inputs $\left(\kappa_{i}=\right.$ 0 ). To see this, note that the marginal effect of input skill intensity on final production skills is given by $\partial h_{i t} / \partial \sigma_{i t}=\beta_{1}+\beta_{2} \kappa_{i}$. The implied coefficients are very similar to the direct estimates of $\beta$ documented above. The interaction results support the presumption that product innovation is one channel through which ITSC works. In addition, they argue against the concern that ITSC is a spurious correlation: ITSC is not present where one would not expect it to appear, and it becomes stronger where one expects intersectoral skill complementarities to play a more important role.

\section{[Insert Table 8 here]}

In Appendix B.3, I analyze whether automation may be an alternative explanation for the findings presented above - if machines replaced low-skilled workers $L$, this would also lead to a rising skilled labor share $h=H /(H+L)$. I find no support for this channel. Finally, it is important to interpret the results from this subsection with caution. The evidence relies on $\hat{\beta}^{A M}$ being statistically significantly larger than $\hat{\beta}^{B M}$. This implicitly assumes that possible endogeneity bias has the same direction and size for both estimates. ${ }^{44}$ In addition, other channels that are associated with product differentiation may drive the findings. Nevertheless, the results provide some support for the product innovation channel.

\subsection{Multiplier Effect and Importance of ITSC}

So far, I have shown that the correlation between input skill intensity and the downstream share of skilled labor is highly significant and robust to the inclusion of various controls. I have interpreted this finding as

\footnotetext{
${ }^{43}$ Because the framework analyzed here potentially involves complementarity among several explanatory variables, I also interact the control variables with input differentiation. This addresses the concern that the $\sigma_{i} \times \kappa_{i}$ interaction alone might capture other effects related to product differentiation. This is the case, for example, if the processing of differentiated intermediates is more $\mathrm{R} \& \mathrm{D}$ intensive, or if the degree of outsourcing is related to $\kappa_{i}$. Input differentiation $\kappa_{i}$ is not included in the regressions, as it is captured by sectoral fixed effects.

${ }^{44}$ For example, endogeneity bias may affect the estimates if unobserved common trends are more pronounced in sectors that use differentiated intermediates - and if such trends span across sectors in different 2-digit categories, so that $\sigma^{2 \mathrm{~d}}$ does not fully account for the bias.
} 
evidence for technology-skill complementarity across sectors. In this final section, I analyze the quantitative importance of ITSC, providing suggestive evidence for the size of the multiplier effect. I begin with a simple extension of the standard SBTC framework that allows for spillovers of skill-biased technology along inputoutput linkages. This setup delivers a multiplier effect. I then estimate the parameter that governs the size of the multiplier, and conclude by discussing the limitations of these estimates.

\section{ITSC and Multiplier Effect in the Standard SBTC Framework}

To illustrate the multiplier effect resulting from ITSC, I sketch an extension to the standard SBTC framework: A complementarity of skill-biased technology across sectors. In the interest of simplicity, I do not model intermediate product linkages explicitly - this is not needed for the main result. To generate the multiplier effect, it is sufficient to introduce a between-sector complementarity in the skill-augmenting productivity term of a CES production function. This simple extension also has the advantage that the modified results can be readily compared to the standard SBTC model.

The standard SBTC setup has two types of labor in a CES production function, producing one final good. ${ }^{45}$ Suppose that there are $i=1, \ldots, N$ sectors. Within each sector, a multiplicity of firms operates under perfect competition and constant returns. A representative firm in sector $i$ produces its output using low-skilled labor $L_{i}$ and high-skilled labor $H_{i}$ :

$$
Y_{i}=\left[\left(A_{i} H_{i}\right)^{\frac{\epsilon-1}{\epsilon}}+L_{i}^{\frac{\epsilon-1}{\epsilon}}\right]^{\frac{\epsilon}{\epsilon-1}}
$$

where $\epsilon$ is the elasticity of substitution between the two labor inputs. $A_{i}$ denotes the relative efficiency of skilled as compared to unskilled workers in sector $i$; increases in $A_{i}$ correspond to SBTC.

I introduce a small but important modification to the standard setup: A complementarity between skillbiased technologies in upstream and downstream sectors. To formalize this concept, I use a multiplicative representation in the spirit of Kremer's (1993) O-Ring theory.

$$
A_{i}=T_{i} \sigma_{i}^{\phi}
$$

The first variable, $T_{i}$, denotes within-sector skill bias in $i$. For example, investment in computers, high-tech equipment, or R\&D in industry $i$ would be reflected as increases in $T_{i}$. Second, $\sigma_{i}$ represents upstream skill bias. To be precise, let $\sigma_{i}$ be the (weighted) average of the skill bias $\left\{A_{j}\right\}_{j \neq i}$ of upstream suppliers to sector $i$. Finally, the parameter $\phi \in[0,1)$ in (6) indicates the strength of the complementarity between upstream and downstream skill bias. If $\phi>0$, the relative productivity of skilled labor in sector $i$ increases in input skill bias. ${ }^{46}$ On the other hand, if $\phi=0$ the model reduces to the standard SBTC setup, where total skill bias $A_{i}$ depends only on the within-sector component $T_{i}$.

\footnotetext{
${ }^{45}$ See Card and DiNardo (2002) and Violante (2006) for a review of the standard SBTC framework.

${ }^{46}$ As a convention, I limit the parameter $\phi$ to be less than unity. For larger values, a unit increase in upstream skill bias would have a larger impact on the productivity of $H_{i}$ than a unit increase of skill bias within the same sector - that is, the complementarity would be extremely strong. In this case, the multiplier cannot be derived.
} 
For simplicity, and to focus attention on the multiplier mechanism, I assume that firms take $T_{i}$ and $\sigma_{i}$ as given and choose $L_{i}$ and $H_{i}$ optimally. Optimization of firms within sectors yields the relative demand for skilled labor:

$$
\frac{H_{i}}{L_{i}}=\left(T_{i} \sigma_{i}^{\phi}\right)^{\epsilon-1}\left(\frac{w_{L}}{w_{H}}\right)^{\epsilon}
$$

Relative skill demand is determined by the inverse aggregate skill premium, by within-sector skill bias $T_{i}$, and input skill bias $\sigma_{i}$. Previous estimates of skill demand focus on the within-sector component $T_{i}$ as a source of skill bias. This approach will not detect the full scope of SBTC if $\phi>0$. In this case, aggregate SBTC will be augmented by a multiplier of skill bias. This is easiest to see in the symmetric case of the model. Let $A_{i}=A, \forall i$, such that $\sigma_{i}=A$. Therefore, (6) simplifies to

$$
A=T^{1 /(1-\phi)}
$$

This equation describes the multiplier effect. To see how it works, I derive the skill premium at the aggregate level from (5).

$$
\frac{w_{H}}{w_{L}}=\left(T^{\frac{\epsilon-1}{\epsilon}}\right)^{1 /(1-\phi)}\left(\frac{L}{H}\right)^{\frac{1}{\epsilon}}
$$

The parameter $\phi$ can be interpreted as the average strength of ITSC in the economy. Note that if $\phi=0$, aggregate skill bias is equal to within-sector skill bias, which corresponds to the standard SBTC framework. A multiplicity of studies following Katz and Murphy (1992) estimate (9) in logs and capture aggregate skill bias by a time trend, commonly finding a large coefficient. However, as discussed above, within-sector drivers of skill demand (represented by $T_{i}$ ) alone cannot explain the full magnitude of the observed skill upgrading. The framework presented here can help to reconcile these findings. With $\phi>0$, intersectoral complementarity delivers a multiplier effect. SBTC in one sector goes hand-in-hand with rising skill bias in other sectors and eventually feeds back into the originating sector. This amplifies within-sector skill bias, as reflected by the exponent $1 /(1-\phi)$, which boosts aggregate skill demand. ${ }^{47}$

\section{Estimates for the Size of the Multiplier Effect}

To shed light on the magnitude of ITSC, I follow the theoretical setup in equation (7), which features within-sector skill bias $T_{i}$ as well as input skill bias $\sigma_{i}$. To derive a measure for the latter, I follow the methodology from Caselli and Coleman (2006). First, I calculate the relative skill bias of production within each sector, which is defined as the ratio of high-skill to low-skill labor efficiency in a CES production function: $A_{i t}^{r e l}=A_{i t}^{H} / A_{i t}^{L}$. The ratio $A_{i t}^{r e l}$ therefore reflects $A_{i}$ in equation (5). It follows directly from (7)

\footnotetext{
${ }^{47}$ This argument is similar to Jones' (2011) model that delivers a multiplier for productivity differences. The multiplier channel, however, is different. In Jones' setup, higher intermediate productivity leads to more output, which feeds back into the production of intermediates. The share of intermediate goods in total revenue is therefore crucial for the size of the multiplier. In the stylized setup presented here, the intermediate input share in total output is not important for ITSC. What counts is the size of the parameter $\phi$, i.e., how strongly skill biased innovation embedded in intermediates, $\sigma_{i}$, is correlated with downstream skill bias, $A_{i}$. Linkages are only important for granting that sectors process each others' output. They are necessary, but not sufficient for the multiplier to exist.
} 
as $A_{i t}^{r e l}=\left(w_{i t, H} / w_{i t, L}\right)^{\epsilon /(\epsilon-1)}\left(H_{i t} / L_{i t}\right)^{1 /(\epsilon-1)} \cdot{ }^{48}$ I then modify equation (1), using $A_{j t}^{r e l}$ to calculate the input skill bias $\sigma_{i t}^{A}$ - the relative skill bias in the production of sector $i$ 's intermediates $j \neq i$ :

$$
\sigma_{i t}^{A}=\sum_{j \neq i} \bar{a}_{i j} A_{j t}^{r e l}
$$

Finally, I take the logarithm of (7) to obtain the estimation equation:

$$
\ln \left(\frac{H_{i t}}{L_{i t}}\right)=\beta \ln \left(\sigma_{i t}^{A}\right)+\gamma Z_{i t}+\alpha_{i}+\alpha_{t}+\varepsilon_{i t},
$$

where the set of controls $Z_{i t}$ accounts for within-sector skill bias $\left(\ln T_{i t}\right)$, using the same variables as in the previous sections. Note that the relative wage term in (7) refers to the economy overall and is thus captured by the time dummies $\alpha_{t}$. In some specifications I also include sector-specific trends, allowing the relative wage to follow different paths in different sectors. Finally, I include fixed effects $\alpha_{i}$ to account for unobserved time-invariant heterogeneity across sectors.

The point estimate of $\beta$ can be used to derive the magnitude of ITSC: $\phi=\beta /(\epsilon-1)$, as implied by (7). Following the SBTC literature, I assume that skilled and unskilled labor are substitutes $(\epsilon>1)$. In the baseline estimates, I use the value of 1.5 in line with Ciccone and Peri (2005) both to calculate $\sigma_{i t}^{A}$ and to derive $\phi .{ }^{49}$ Table 9 presents the estimates of $\beta$ - in panel A for the full sample, and in panel B for the quinquennial benchmark years. Column 1 includes only input skill bias as explanatory variable. The coefficient is highly significant and positive. Columns 2 and 3 add fixed effects and controls, respectively, and column 4 additionally uses sector-specific time trends. Finally, columns 5 and 6 repeat the analysis for $\sigma_{i t}^{A, 2 \mathrm{~d}}$, excluding inputs from the same 2-digit SIC industries.

\section{[Insert Table 9 here]}

The point estimates of $\beta$ when including all controls and fixed effects (columns 3-6) vary between 0.08 and 0.22 , which implies that $\phi$ ranges between 0.16 and 0.44 . Following (8), this yields a multiplier of $1 /(1-\phi)=1.19-1.79$, i.e., ITSC amplifies within-sector skill bias by approximately $20-80 \%$. The average of all estimates in columns 3-6 gives $\phi \approx 0.25$, and thus a multiplier effect of 1.33 . If within-sector skill bias explains one half of the observed increase in skill demand, ITSC delivers another 17\%, according to the average parameter estimate. Appendix B.4 checks the robustness of these results. First, estimating equation (11) in differences also yields highly significant but on average slightly smaller coefficients spanning the range $0.04-0.13$, which implies a range of 0.08-0.26 for $\phi$. Second, I use alternative values for the elasticity of substitution $\epsilon$. Both $\epsilon=1.25$ and $\epsilon=2.0$ yield very similar results as the baseline estimation. Third, I estimate the logarithm of (6) instead of (7), obtaining direct estimates of $\phi$ in the approximate range 0.15-0.3. Altogether, most parameters in these robustness checks (when including all controls and fixed effects) fall

\footnotetext{
${ }^{48}$ Caselli and Coleman derive $A_{i t}^{H}$ and $A_{i t}^{L}$ explicitly for a cross-section of countries. For my purposes, the relative skill bias is sufficient.

${ }^{49}$ For now, I treat $\epsilon$ as a given constant, so that estimates of $\phi$ and $\beta$ have the same standard errors. In Appendix B.4 I also treat $\epsilon$ as a random variable and find very similar results.
} 
in the approximate range 0.1-0.4, implying a multiplier effect of about 1.1-1.7. Finally, Appendix B.4 also reports standard errors for the multiplier when $\epsilon$ is treated as a random variable. Using previous estimates from the literature for $\epsilon$, I derive a multiplier distribution with mean approximately 1.4 and a standard deviation of about 0.4 , which is in line with the range of estimates obtained above.

The estimated magnitude of ITSC has to be interpreted with caution. It hinges on a simplified representation of ITSC in the SBTC framework, which is likely more complex in reality. In addition, endogeneity and simultaneity bias are serious concerns. For example, the simplified model only incorporates the effect of upstream skill bias on downstream skill demand, but not the opposite causal direction. If the latter is important, $\beta$ will be overestimated. Simultaneity bias has the same consequence: Common trends may drive skill upgrading in sectors that share input-output linkages, and this would lead to overestimates of $\beta$. The regressions above address this concern by including sector-specific time trends. However, if common trends are non-linear, the potential for bias remains. As a consequence, the derived magnitude of ITSC should be interpreted as merely suggestive, because the size of the bias is unknown.

\section{Conclusion}

While intermediate inputs account for more than half of a final product's value, intersectoral linkages have been ignored as a source of skill bias. At the same time, existing empirical work, focusing on within-sector skill bias, cannot account for the full scope of skill upgrading in recent decades. This paper adds intersectoral skill complementarities that operate through the use of intermediate products. In this setup, SBTC in one sector goes hand-in-hand with skill upgrading in many other sectors, which delivers a multiplier that augments sector-level SBTC into larger aggregate skill bias. This can help to explain why within-sector studies fail to account for the full scope of aggregate SBTC.

My empirical results are derived from detailed 4-digit sectors in U.S. manufacturing over the period 1958-2005. I analyze input skill intensity, which measures the skills embedded in a sector's intermediate inputs. I construct this variable by combining product flows from input-output tables with worker characteristics from the NBER Manufacturing Industry Database. Input skill intensity correlates strongly with final production skills. This finding is robust to the inclusion of numerous control variables previously suggested in the SBTC literature, as well as to using alternative measures of input skill intensity. The presented evidence implies intersectoral technology-skill complementarity (ITSC). This result does not come as a surprise. It combines the well-documented findings of a technology-skill complementarity within sectors with technological spillovers across sectors.

My sample spans a period of relatively constant skill premia - until the late 1970s - and then a period of rapidly increasing skill premia starting in the 1980s. While outsourcing and IT capital boosted skill demand particularly in the second period, the coefficients related to ITSC are roughly constant throughout the sample. This suggests that ITSC contributed persistently to the secular increase in skill demand during most of the 20th century (Goldin and Katz, 2009).

Downstream industries using differentiated intermediates purchase relatively more embedded innova- 
tion. I show that ITSC is stronger among sectors linked through more differentiated intermediates. This suggests that product innovation is one potential channel through which spillovers work. Finally, I introduce ITSC in the standard SBTC model and derive a reduced form equation to estimate the size of the multiplier effect. The empirical framework builds on spillovers along input-output linkages. These are difficult to identify, and endogeneity bias is a major concern when interpreting the magnitude of coefficients. Subject to this caveat, the results suggest that ITSC is quantitatively important, explaining about $17 \%$ of skill upgrading in U.S. manufacturing.

In combination, the results of this study suggest that (i) there is a strong complementarity between upstream use of skilled labor and its downstream employment, (ii) the complementarity is - at least partially - a result of spillovers through the use of intermediates, and (iii) this intersectoral complementarity leads to a multiplier effect that augments given within-sector skill bias and thus contributed to the rise in skill demand over the last decades. These findings may have important economy-wide implications. For example, the multiplier effect will tend to increase the social returns to education and R\&D. To gauge the magnitude of this aggregate effect, future research should analyze whether ITSC carries over to sectors outside of manufacturing. 


\section{References}

Acemoglu, D. (1998). Why Do New Technologies Complement Skills? Directed Technical Change And Wage Inequality. Quarterly Journal of Economics 113(4), 1055-1089.

Acemoglu, D. (2002a). Directed Technical Change. Review of Economic Studies 69(4), 781-809.

Acemoglu, D. (2002b). Technical Change, Inequality, and the Labor Market. Journal of Economic Literature 40(1), $7-72$.

Acemoglu, D. (2007). Equilibrium Bias of Technology. Econometrica 75(5), 1371-1409.

Acemoglu, D. and D. Autor (2011). Skills, Tasks and Technologies: Implications for Employment and Earnings. Handbook of Labor Economics 4, 1043-1171.

Autor, D. H., L. F. Katz, and M. S. Kearney (2008). Trends in U.S. Wage Inequality: Revising the Revisionists. Review of Economics and Statistics 90(2), 300-323.

Autor, D. H., L. F. Katz, and A. B. Krueger (1998). Computing Inequality: Have Computers Changed the Labor Market? Quarterly Journal of Economics 113(4), 1169-1214.

Autor, D. H., F. Levy, and R. J. Murnane (2003). The Skill Content of Recent Technological Change: An Empirical Exploration. Quarterly Journal of Economics 118(4), 1279-1333.

Bartel, A. P. and F. Lichtenberg (1987). The Comparative Advantage of Educated Workers in Implementing New Technology. Review of Economics and Statistics 69(1), 1-11.

Bartelsman, E. J. and W. Grey (1996). The NBER Manufacturing Productivity Database. NBER Technical Working Paper 205.

Basu, S. (1995). Intermediate Goods and Business Cycles: Implications for Productivity and Welfare. American Economic Review 85(3), 512-531.

Becker, R., J. Haltiwanger, R. Jarmin, S. Klimek, and D. Wilson (2006). Micro and Macro Data Integration: The Case of Capital. In D. W. Jorgenson, J. S. Landefeld, and W. D. Nordhaus (Eds.), A New Architecture for the U.S. Nation Accounts. University of Chicago Press.

Berman, E., J. Bound, and Z. Griliches (1994). Changes in the Demand for Skilled Labor within U.S. Manufacturing: Evidence from the Annual Survey of Manufacturers. Quarterly Journal of Economics 109(2), 367-397.

Berman, E., J. Bound, and S. Machin (1998). Implications of Skill-Biased Technological Change: International Evidence. Quarterly Journal of Economics 113(4), 1245-1279.

Berndt, E. R., C. J. Morrison, and L. S. Rosenblum (1992). High-Tech Capital Formation and Labor Composition in U.S. Manufacturing Industries: An Exploratory Analysis. NBER Working Paper 4010.

Bertrand, M., E. Duflo, and S. Mullainathan (2004). How Much Should We Trust Differences-in-Differences Estimates? Quarterly Journal of Economics 119(1), 249-275.

Blalock, G. and P. J. Gertler (2008). Welfare Gains from Foreign Direct Investment through Technology Transfer to Local Suppliers. Journal of International Economics 74(2), 402-421.

Blanchard, O. and M. Kremer (1997). Disorganization. Quarterly Journal of Economics 112(4), 1091-1126.

Bound, J. and G. Johnson (1992). Changes in the Structure of Wages in the 1980s: An Evaluation of Alternative Explanations. American Economic Review 82(3), 371-392.

Bresnahan, T. F., E. Brynjolfsson, and L. M. Hitt (2002). Information Technology, Workplace Organization and the Demand for Skilled Labor: Firm-Level Evidence. Quarterly Journal of Economics 117(1), 339-376.

Card, D. and J. E. DiNardo (2002). Skill-Biased Technological Change and Rising Wage Inequality: Some Problems and Puzzles. Journal of Labor Economics 20(4), 733-783.

Caselli, F. and W. J. Coleman (2006). The World Technology Frontier. American Economic Review 96(3), 499-522. 
Ciccone, A. (2002). Input Chains and Industrialization. Review of Economic Studies 69, 565-587.

Ciccone, A. and G. Peri (2005). Long-run Substitutability Between More and Less Educated Workers: Evidence from U.S. States 1950-1990. Review of Economics and Statistics 87(4), 652-663.

Crinò, R. (2010). Service Offshoring and White-Collar Employment. Review of Economic Studies 77, 595-632.

DiNardo, J. E. and J.-S. Pischke (1997). The Returns to Computer Use Revisited: Have Pencils Changed the Wage Structure Too? Quarterly Journal of Economics 112(1), 291-303.

Doms, M., T. Dunne, and K. R. Troske (1997). Workers, Wages, and Technology. Quarterly Journal of Economics 112(1), 253-290.

Epifani, P. and G. Gancia (2006). Increasing Returns, Imperfect Competition, and Factor Prices. Review of Economics and Statistics 88(4), 583-598.

Feenstra, R. C. (2004). Advanced International Trade: Theory and Evidence. Princeton, N.J.: Princeton University Press.

Feenstra, R. C. and G. H. Hanson (1999). The Impact of Outsourcing and High-Technology Capital on Wages: Estimates for the United States, 1979-1990. Quarterly Journal of Economics 114(3), 907-940.

Fox, J. T. and V. Smeets (2011). Does Input Quality Drive Measured Differences in Firm Productivity? NBER Working Paper 16853.

Goldin, C. and L. F. Katz (1998). The Origins of Technology-Skill Complementarity. Quarterly Journal of Economics 113(3), 693-732.

Goldin, C. and L. F. Katz (2007). Long-Run Changes in the Wage Structure: Narrowing, Widening, Polarizing. Brookings Papers on Economic Activity 38(2), 135-168.

Goldin, C. and L. F. Katz (2009). The Race Between Education and Technology. Harvard University Press.

Goos, M. and A. Manning (2007). Lousy and Lovely Jobs: The Rising Polarization of Work in Britain. Review of Economics and Statistics 89(1), 118-133.

Griliches, Z. (1969). Capital-Skill Complementarity. Review of Economics and Statistics 51(4), 465-468.

Hirschman, A. O. (1958). The Strategy of Economic Development. New Haven, CT: Yale University Press.

Jones, C. I. (2011). Intermediate Goods and Weak Links in the Theory of Economic Development. American Economic Journal: Macroeconomics (forthcoming).

Katz, L. F. and D. H. Autor (1999). Changes in the Wage Structure and Earnings Inequality. In O. Ashenfelter and D. E. Card (Eds.), Handbook of Labor Economics, Volume 3, Chapter 26, pp. 1463-1555. Amsterdam, North Holland: Elsevier.

Katz, L. F. and K. M. Murphy (1992). Changes in Relative Wages, 1963-1987: Supply and Demand Factors. Quarterly Journal of Economics 107(1), 35-78.

Keller, W. (2004). International Technology Diffusion. Journal of Economic Literature 42(3), 752-782.

King, M., S. Ruggles, J. T. Alexander, S. Flood, K. Genadek, M. B. Schroeder, B. Trampe, and R. Vick (2010). Integrated Public Use Microdata Series, Current Population Survey: Version 3.0. Minneapolis: University of Minnesota. [Machine-readable database].

Koo, J. (2005). Technology Spillovers, Agglomeration, and Regional Economic Development. Journal of Planning Literature 20(2), 99-115.

Kremer, M. (1993). The O-Ring Theory of Economic Development. Quarterly Journal of Economics 108(3), 551-575.

Krueger, A. B. (1993). How Computers Changed the Wage Structure: Evidence from Microdata, 1984-1989. Quarterly Journal of Economics 108(1), 33-60.

Krusell, P., L. E. Ohanian, J.-V. Ríus-Rull, and G. L. Violante (2000). Capital-Skill Complementarity and Inequality: A Macroeconomics Analysis. Econometrica 68(5), 1029-1053. 
Kugler, M. and E. Verhoogen (2012). Prices, Plant Size, and Product Quality. Review of Economic Studies 79(1), 307-339.

Leamer, E. E. (1996). Wage Inequality from International Competition and Technological Change: Theory and Country Experience. American Economic Review 86(2), 309-314.

Leontief, W. (1936). Quantitative Input and Output Relations in the Economic System of the United States. Review of Economics and Statistics 18(3), 105-125.

Levy, F. and R. J. Murnane (1996). With What Skills are Computers a Complement? American Economic Review Papers and Proceedings 86(2), 258-262.

Machin, S. and J. van Reenen (1998). Technology and Changes in Skill Structure: Evidence from Seven OECD Countries. Quarterly Journal of Economics 113(4), 1215-1244.

Milgrom, P. and J. Roberts (1990). The Economics of Modern Manufacturing: Technology, Strategy, and Organization. American Economic Review 80(3), 511-528.

Nelson, R. R. and E. S. Phelps (1966). Investment in Humans, Technological Diffusion, and Economic Growth. American Economic Review 56(2), 69-75.

Nunn, N. (2007). Relationship-Specificity, Incomplete Contracts and the Pattern of Trade. Quarterly Journal of Economics 122(2), 569-600.

Pavcnik, N. (2003). What Explains Skill Upgrading in Less Developed Countries? Journal of Development Economics 71(2), 311-328.

Pavitt, K. (1984). Patterns of Technical Change: Towards a Taxonomy and a Theory. Research Policy 13(6), 342-373.

Rauch, J. E. (1999). Networks versus Markets in International Trade. Journal of International Economics 48(1), 7-35.

Rodríguez-Clare, A. (1996). Multinationals, Linkages, and Economic Development. American Economic Review 86(4), 852-873.

Sanders, M. and B. ter Weel (2000). Skill-Biased Technical Change: Theoretical Concepts, Empirical Problems and a Survey of the Evidence. DRUID Working Papers.

Scherer, F. M. (1982). Inter-Industry Technology Flows in the United States. Research Policy 11(4), 227-245.

Schmookler, J. (1966). Invention and Economic Growth. Cambridge, MA: Harvard University Press.

Schott, P. K. (2010). U.S. Manufacturing Exports and Imports by SIC or NAICS Category and Partner Country, 1972 to 2005. mimeo.

Verhoogen, E. (2008). Trade, Quality Upgrading and Wage Inequality in the Mexican Manufacturing Sector. Quarterly Journal of Economics 123(2), 489-530.

Violante, G. L. (2006). Skill-Biased Technical Change. In L. Blume and S. Durlauf (Eds.), The New Palgrave Dictionary of Economics (2 ed.). Palgrave Macmillan.

Wood, A. (1998). Globalisation and the Rise in Labour Market Inequalities. Economic Journal 108(450), 1463-1482.

Yi, K.-M. (2003). Can Vertical Specialization Explain the Growth of World Trade? Journal of Political Economy 111(1), 52-102.

Zhu, S. C. (2005). Can Product Cycles Explain Skill Upgrading? Journal of International Economics 66(1), 131-155. 


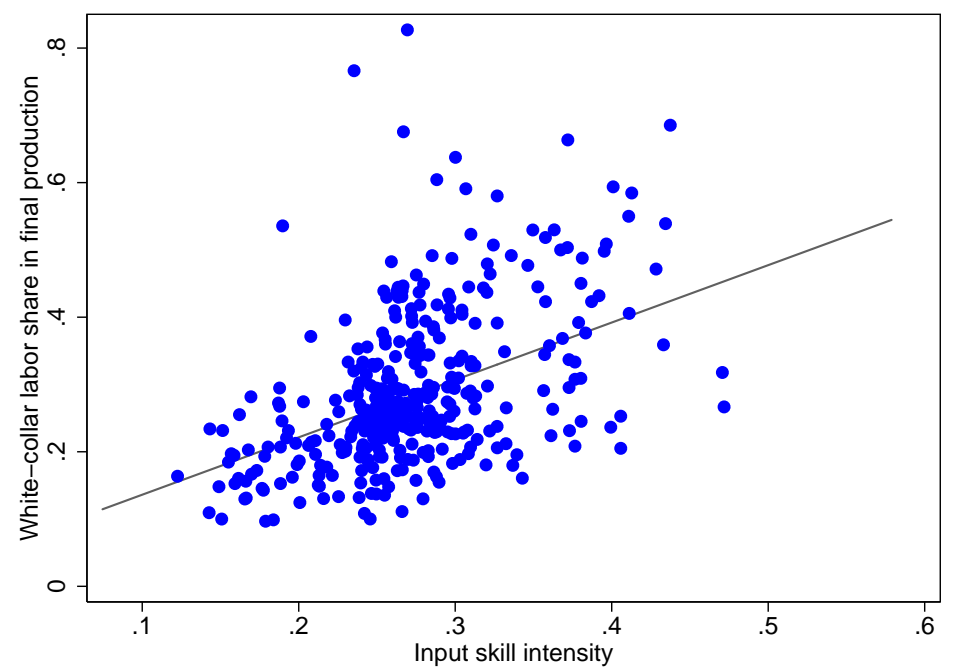

Figure 1: Skilled labor share in final production vs. input skill intensity

Notes: Data are for 358 U.S. manufacturing sectors in 1992. Input skill intensity is calculated as the weighted average share of white-collar workers employed in the production of a sector's intermediate inputs. Only inputs purchased outside a sector are taken into account. The corresponding regression has a slope parameter of .957 with a standard error of .101. See Section 2 for a formal description and data sources, and Section 3 for detailed regression results and robustness. 

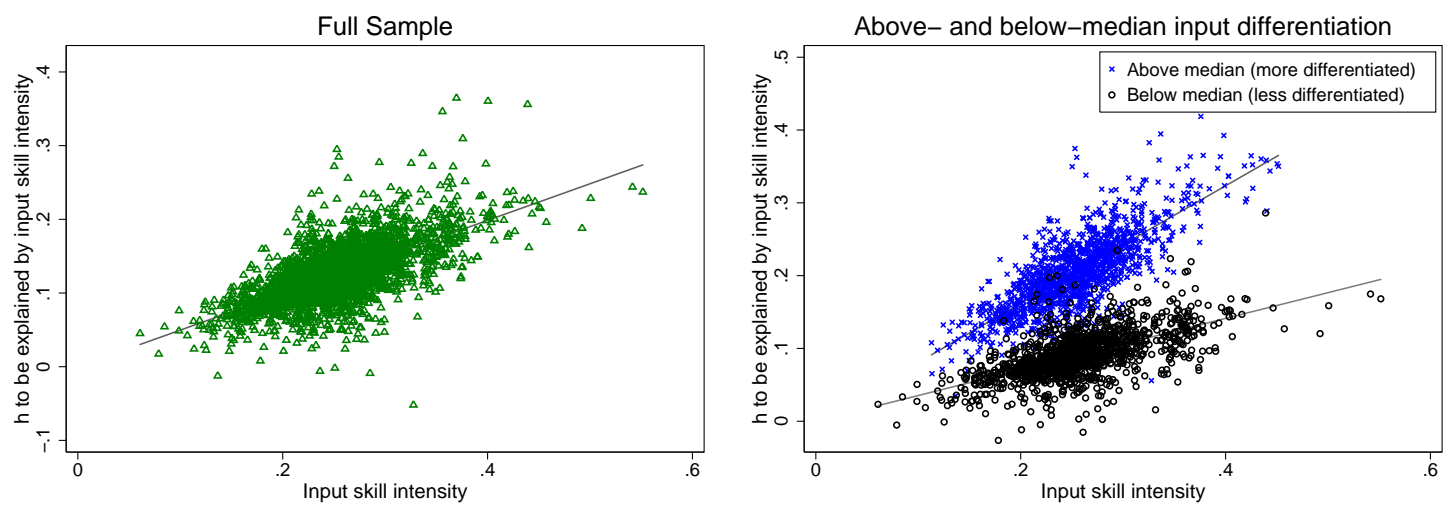

Figure 2: Partial scatter plots: Skilled labor share $\left(h_{i t}\right)$ vs. input skill intensity $\left(\sigma_{i t}\right)$

Notes: Figure based on quinquennial data, 1967-2002. The measure of input differentiation $\kappa_{i}$ is calculated as described in Appendix A.3, yielding a median of .52. The vertical axis shows $h_{i t}-\left(\hat{\alpha}_{i}+\hat{\alpha}_{t}+\hat{\gamma} Z_{i t}\right)$; notice that $\hat{\beta} \sigma_{i t}$ does not appear in this equation. Coefficient estimates $\hat{\alpha}_{i}, \hat{\alpha}_{t}, \hat{\beta}$, and $\hat{\gamma}$ are obtained by estimating (2) for the quinquennial sample (2806 obs.), where the controls $Z_{i t}$ include: Equipment per worker ( $k^{\text {equip }}$ ), office and computer capital $(O C A M / K)$, non-computing high-tech capital $(H T / K-O C A M / K), \mathrm{R} \& \mathrm{D}$ intensity $\left(R \& D_{l a g}\right)$, and the broad and narrow outsourcing measures $\left(O S^{\text {narr }}\right.$ and $\left.O S^{\text {broad }}-O S^{\text {narr }}\right)$. In the left panel, $\hat{\beta} \sigma_{i t}$ is estimated with a coefficient of .50 (.12). In the right panel, this coefficient is split into $\hat{\beta}^{A M} \sigma_{i t}^{A M}+\hat{\beta}^{B M} \sigma_{i t}^{B M}$, representing above- and below-median input differentiation, respectively (see equation (4)). The coefficient estimates are $\hat{\beta}^{A M}=.81(.15)$ and $\hat{\beta}^{B M}=.35(.11)$.

Table 1: The ten 4-digit industries with smallest and largest change in $\sigma_{i t}, 1958-2005$

\begin{tabular}{|c|c|c|c|}
\hline \multicolumn{2}{|r|}{$\underline{\text { Smallest change }}$} & \multicolumn{2}{|r|}{$\underline{\text { Largest change }}$} \\
\hline$\triangle \sigma_{i t}$ & Industry description & $\triangle \sigma_{i t}$ & Industry description \\
\hline-.045 & Leather tanning \& finishing & .074 & Carbon black \\
\hline-.021 & Thread mills & .122 & Aircraft \\
\hline-.024 & Narrow fabrics mills & .128 & Search and navigation equipment \\
\hline-.024 & Ice cream and frozen desserts & .129 & Jewelry, precious metal \\
\hline-.033 & Cheese, natural and processed & .130 & Calculating and accounting equipment \\
\hline-.035 & Cordage and twine & .133 & Guided missiles and space vehicles \\
\hline-.046 & Yarn mills and finishing of textiles & .133 & Instruments to measure electricity \\
\hline-.049 & Leather tanning and finishing & .134 & Telephone and telegraph apparatus \\
\hline-.069 & Sausages and other prepared meats & .144 & Electronic computing equip. \\
\hline-.080 & Tire cord and fabrics & .149 & Prerecorded records and tapes \\
\hline-.123 & Creamery butter & .149 & Communication equipment \\
\hline
\end{tabular}

Note: Input skill intensity $\sigma_{i t}$ calculated as in (1). Reported figures are rounded from seven digits to three digits. 
Table 2: Correlations between input skill intensity and control variables

\begin{tabular}{|c|c|c|c|c|c|c|}
\hline \multirow[b]{3}{*}{ Measure } & \multirow{2}{*}{\multicolumn{2}{|c|}{$\begin{array}{l}\text { Input skill } \\
\text { intensity }\end{array}$}} & \multicolumn{2}{|c|}{ Capital } & \multirow{3}{*}{$\begin{array}{l}\mathrm{R} \& \mathrm{D} / \\
\text { sales } \\
R \& D_{l a g}\end{array}$} & \multirow{3}{*}{$\begin{array}{l}\begin{array}{l}\text { Out- } \\
\text { sourcing }\end{array} \\
O S^{\text {narr }}\end{array}$} \\
\hline & & & \multirow{2}{*}{$\begin{array}{l}\text { per } \\
\text { worker } \\
k^{\text {equip }}\end{array}$} & \multirow{2}{*}{$\begin{array}{l}\text { High- } \\
\text { Tech } \\
H T / K\end{array}$} & & \\
\hline & $\sigma$ & $\sigma^{2 \mathrm{~d}}$ & & & & \\
\hline$\sigma$ & 1 & & & & & \\
\hline$\sigma^{2 \mathrm{~d}}$ & $.69 * * *$ & 1 & & & & \\
\hline$k^{\text {equip }}$ & $.12 * * *$ & $.17 * * *$ & 1 & & & \\
\hline$H T / K$ & $.17 * * *$ & $.09 * * *$ & $-.05^{* *}$ & 1 & & \\
\hline$R \& D_{l a g}$ & $.17 * * *$ & $.10 * * *$ & $-.02 * * *$ & $.25^{* * * *}$ & 1 & \\
\hline$O S^{\text {narr }}$ & $.18 * * *$ & $.16^{* * * *}$ & $.11 * * *$ & $.04 * * *$ & $.16^{* * * *}$ & 1 \\
\hline
\end{tabular}

Notes: Annual data, 1958-2005, for 358 U.S. manufacturing sectors. Reported numbers are pairwise correlation coefficients, controlling for sector and time fixed effects. Key: *** significant at $1 \% ; * * 5 \% ; * 10 \%$.

Table 3: Final production skills, input skill intensity, and controls. Dependent variable is $h$.

\begin{tabular}{|c|c|c|c|c|c|c|}
\hline \multirow[t]{2}{*}{ Input skill measure } & \multicolumn{5}{|c|}{ - Baseline: $\sigma_{i t} \longrightarrow$} & \multirow{2}{*}{$\begin{array}{l}\sigma_{i t}^{2 \mathrm{~d}} \\
(6)\end{array}$} \\
\hline & (1) & (2) & (3) & (4) & (5) & \\
\hline Input skill intensity: & $\begin{array}{l}1.360 * * * \\
(.162)\end{array}$ & $\begin{array}{l}1.094 * * * \\
(.100)\end{array}$ & $\begin{array}{l}.982 * * * \\
(.163)\end{array}$ & $\begin{array}{l}.883 * * * \\
(.159)\end{array}$ & $\begin{array}{l}.662 * * * \\
(.119)\end{array}$ & $\begin{array}{l}.539 * * * \\
(.167)\end{array}$ \\
\hline Equipment per worker: $k^{\text {equip }}$ & & & & $\begin{array}{l}-.0660 \\
(.049)\end{array}$ & $\begin{array}{l}-.0498 \\
(.043)\end{array}$ & $\begin{array}{l}-.0441 \\
(.046)\end{array}$ \\
\hline Office equipment: $O C A M / K$ & & & & $\begin{array}{l}.274 \\
(.168)\end{array}$ & $\begin{array}{l}.145 \\
(.166)\end{array}$ & $\begin{array}{l}.143 \\
(.163)\end{array}$ \\
\hline $\begin{array}{l}\text { High-Tech capital: Difference } \\
(H T / K-O C A M / K)\end{array}$ & & & & $\begin{array}{l}.483 * * \\
(.191)\end{array}$ & $\begin{array}{l}.497 * * \\
(.192)\end{array}$ & $\begin{array}{l}.571 * * * \\
(.184)\end{array}$ \\
\hline $\mathrm{R} \& \mathrm{D}$ intensity $R \& D_{\text {lag }}$ & & & & & $\begin{array}{l}.650 * * * \\
(.205)\end{array}$ & $\begin{array}{l}.742 * * * \\
(.212)\end{array}$ \\
\hline $\begin{array}{l}\text { Outsourcing: } O S^{\text {narr }} \\
\text { (narrow) }\end{array}$ & & & & & $\begin{array}{l}.0888^{*} \\
(.048)\end{array}$ & $\begin{array}{l}.107 * * \\
(.051)\end{array}$ \\
\hline $\begin{array}{l}\text { Outsourcing (broad): difference } \\
\left(O S^{\text {broad }}-O S^{\text {narr }}\right)\end{array}$ & & & & & $\begin{array}{l}.189 * * * \\
(.064)\end{array}$ & $\begin{array}{l}.206 * * * \\
(.065)\end{array}$ \\
\hline Sector fixed effects & no & yes & yes & yes & yes & yes \\
\hline Time fixed effects & no & no & yes & yes & yes & yes \\
\hline $\begin{array}{l}\text { Adjusted } R^{2} \\
R^{2} \text { (within) } \\
\text { Observations }\end{array}$ & $\begin{array}{l}.297 \\
- \\
17.184\end{array}$ & $\begin{array}{l}.950 \\
.379 \\
17.184\end{array}$ & $\begin{array}{l}.951 \\
.392 \\
17.184\end{array}$ & $\begin{array}{l}.954 \\
.429 \\
17.184\end{array}$ & $\begin{array}{l}.958 \\
.476 \\
16.633\end{array}$ & $\begin{array}{l}.957 \\
.459 \\
16.633\end{array}$ \\
\hline
\end{tabular}

Notes: Annual data, 1958-2005, for 358 U.S. manufacturing sectors. Clustered standard errors (by sector) in parentheses. Key: *** significant at $1 \%$;* 5\%; *10\%. All regressions are weighted by sectors' average share in manufacturing employment. 
Table 4: Final production skills, input skill intensity, and controls. Dependent variable is $h$.

\begin{tabular}{|c|c|c|c|c|c|c|}
\hline \multirow[t]{2}{*}{ Input skill measure } & \multirow[b]{2}{*}{ (1) } & \multirow[b]{2}{*}{$(2)$} & \multirow{2}{*}{$\begin{array}{l}-\sigma_{i t} \\
\text { (3) }\end{array}$} & \multirow[b]{2}{*}{$(4)$} & \multirow[b]{2}{*}{$(5)$} & \multirow{2}{*}{$\begin{array}{l}\sigma_{i t}^{2 \mathrm{~d}} \\
(6)\end{array}$} \\
\hline & & & & & & \\
\hline $\begin{array}{l}\text { Input skill intensity: } \sigma_{i} \\
\qquad \sigma_{i} \times I^{t \geq 1980}\end{array}$ & $\begin{array}{l}1.376 * * * \\
(.185) \\
-.0105 \\
(.019)\end{array}$ & $\begin{array}{l}.901 * * * \\
(.120) \\
.0301 * * \\
(.012)\end{array}$ & $\begin{array}{l}.768 * * * \\
(.147) \\
.162 * * \\
(.073)\end{array}$ & $\begin{array}{l}.591 * * * \\
(.118) \\
.0561 \\
(.064)\end{array}$ & $\begin{array}{l}.591 * * * \\
(.118) \\
.0561 \\
(.064)\end{array}$ & $\begin{array}{l}.488 * * * \\
(.188) \\
-.00406 \\
(.064)\end{array}$ \\
\hline $\begin{array}{l}\text { Equipment per worker: } k^{\text {equip }} \\
\qquad k^{\text {equip }} \times I^{t \geq 1980}\end{array}$ & & & & $\begin{array}{l}-.113 \\
(.100) \\
.0584 \\
(.093)\end{array}$ & $\begin{array}{l}-.113 \\
(.100) \\
.0584 \\
(.093)\end{array}$ & $\begin{array}{l}-.122 \\
(.096) \\
.0716 \\
(.088)\end{array}$ \\
\hline $\begin{array}{l}\text { Office equipment: } O C A M / K \\
\qquad O C A M / K \times I^{t \geq 1980}\end{array}$ & & & & $\begin{array}{l}-.331 \\
(.293) \\
.538 * \\
(.315)\end{array}$ & $\begin{array}{l}-.331 \\
(.293) \\
.538 * \\
(.315)\end{array}$ & $\begin{array}{l}-.366 \\
(.294) \\
.544^{*} \\
(.313)\end{array}$ \\
\hline $\begin{array}{l}\text { High-Tech capital: Difference } \\
(H T / K-O C A M / K) \\
\quad(H T / K-O C A M / K) \times I^{t \geq}\end{array}$ & & & & $\begin{array}{l}.258 \\
(.253) \\
.0803 \\
(.237)\end{array}$ & $\begin{array}{l}.258 \\
(.253) \\
.0803 \\
(.237)\end{array}$ & $\begin{array}{l}.202 \\
(.266) \\
.261 \\
(.210)\end{array}$ \\
\hline $\begin{array}{l}\text { R\&D intensity } R \& D_{l a g} \\
\qquad R \& D_{l a g} \times I^{t \geq 1980}\end{array}$ & & & & $\begin{array}{l}1.043^{* * *} \\
(.307) \\
-.394 * \\
(.230)\end{array}$ & $\begin{array}{l}1.043 * * * \\
(.307) \\
-.394 * \\
(.230)\end{array}$ & $\begin{array}{l}1.028 * * * \\
(.302) \\
-.285 \\
(.224)\end{array}$ \\
\hline $\begin{array}{l}\text { Outsourcing: } O S^{\text {narr }} \\
\quad \text { (narrow) } \\
\quad\left(O S^{\text {broad }}-O S^{\text {narr }}\right) \times I^{t \geq 1980}\end{array}$ & & & & $\begin{array}{c}.0421 \\
(.056) \\
.0589 \\
(.056)\end{array}$ & $\begin{array}{r}.0421 \\
(.056) \\
.0589 \\
(.056)\end{array}$ & $\begin{array}{r}.0631 \\
(.060) \\
.0585 \\
(.058)\end{array}$ \\
\hline $\begin{array}{l}\text { Outsourcing (broad): difference } \\
\left(O S^{\text {broad }}-O S^{\text {narr }}\right) \\
\quad\left(O S^{\text {broad }}-O S^{\text {narr }} \times I^{t \geq 1980}\right)\end{array}$ & & & & $\begin{array}{l}-.0575 \\
(.144) \\
.257 * \\
(.138)\end{array}$ & $\begin{array}{l}-.0575 \\
(.144) \\
.257 * \\
(.138)\end{array}$ & $\begin{array}{l}-.0484 \\
(.141) \\
.272 * * \\
(.132)\end{array}$ \\
\hline $\begin{array}{l}\text { Sector fixed effects } \\
\text { Time fixed effects }\end{array}$ & $\begin{array}{l}\text { no } \\
\text { no }\end{array}$ & $\begin{array}{l}\text { yes } \\
\text { no }\end{array}$ & $\begin{array}{l}\text { yes } \\
\text { yes }\end{array}$ & $\begin{array}{l}\text { yes } \\
\text { yes }\end{array}$ & $\begin{array}{l}\text { yes } \\
\text { yes }\end{array}$ & $\begin{array}{l}\text { yes } \\
\text { yes }\end{array}$ \\
\hline $\begin{array}{l}\text { Adjusted } R^{2} \\
R^{2} \text { (within) } \\
\text { Observations }\end{array}$ & $\begin{array}{l}.297 \\
- \\
17,184\end{array}$ & $\begin{array}{l}.950 \\
.385 \\
17,184\end{array}$ & $\begin{array}{l}.952 \\
.404 \\
17,184\end{array}$ & $\begin{array}{l}.959 \\
.491 \\
16,633\end{array}$ & $\begin{array}{l}.959 \\
.491 \\
16,633\end{array}$ & $\begin{array}{l}.958 \\
.473 \\
16,633\end{array}$ \\
\hline
\end{tabular}

Notes: Annual data, 1958-2005, for 358 U.S. manufacturing sectors. Clustered standard errors (by sector) in parentheses. Key: *** significant at $1 \%$;* 5\%; *10\%. All regressions are weighted by sectors' average share in manufacturing employment. $I^{t \geq 1980}$ is a dummy variable that equals one from 1980 onwards. 
Table 5: Input skill intensity with time-varying input shares. Dependent variable is $h_{i t}$.

\begin{tabular}{|c|c|c|c|c|c|c|}
\hline \multirow[t]{2}{*}{ Input skill measure } & \multicolumn{2}{|c|}{$\sigma_{i t}$} & \multicolumn{2}{|c|}{$\sigma_{i t}^{2 \mathrm{~d}}$} & \multicolumn{2}{|c|}{$S_{i t}$} \\
\hline & $(1)$ & $(2)$ & (3) & (4) & $(5)$ & (6) \\
\hline \multicolumn{7}{|l|}{ Input skill intensity } \\
\hline Skill component: $\sigma_{i t} / \sigma_{i t}^{2 \mathrm{~d}}$ & $\begin{array}{l}.915^{* * * *} \\
(.182)\end{array}$ & $\begin{array}{l}.586 * * * \\
(.130)\end{array}$ & $\begin{array}{l}.651 * * * \\
(.202)\end{array}$ & $\begin{array}{l}.325^{* *} \\
(.161)\end{array}$ & & \\
\hline Input mix component: $\tau_{i t} / \tau_{i t}^{2 \mathrm{~d}}$ & $\begin{array}{l}.177 * \\
(.099)\end{array}$ & $\begin{array}{c}.0906 \\
(.078)\end{array}$ & $\begin{array}{l}.0571 \\
(.090)\end{array}$ & $\begin{array}{l}-.0163 \\
(.077)\end{array}$ & & \\
\hline Covariance component: $\rho_{i t} / \rho_{i t}^{2 \mathrm{~d}}$ & $\begin{array}{l}.627 * * \\
(.255)\end{array}$ & $\begin{array}{l}.427 * \\
(.227)\end{array}$ & $\begin{array}{l}.474 * \\
(.270)\end{array}$ & $\begin{array}{c}.279 \\
(.248)\end{array}$ & & \\
\hline All together: $S_{i t}=\sigma_{i t}+\tau_{i t}+\rho_{i t}$ & & & & & $\begin{array}{l}.396^{* * * *} \\
(.110)\end{array}$ & $\begin{array}{l}.216 * * * \\
(.077)\end{array}$ \\
\hline Control variables & no & yes & no & yes & no & yes \\
\hline Sector fixed effects & yes & yes & yes & yes & yes & yes \\
\hline Time fixed effects & yes & yes & yes & yes & yes & yes \\
\hline Adjusted $R^{2}$ & .959 & .964 & .955 & .962 & .956 & .963 \\
\hline$R^{2}$ (within) & .433 & .504 & .383 & .485 & .401 & .491 \\
\hline Observations & 2,806 & 2,806 & 2,806 & 2,806 & 2,806 & 2,806 \\
\hline
\end{tabular}

Notes: Quinquennial data, 1967-2005, for 358 U.S. manufacturing sectors. Clustered standard errors (by sector) in parentheses. Key: $* * *$ significant at $1 \% ; * * 5 \% ; * 10 \%$. All regressions are weighted by sectors' average share in manufacturing employment. Control variables include: Equipment per worker $\left(k^{\text {equip }}\right)$, office and computer capital $(O C A M / K)$, noncomputing high-tech capital $(H T / K-O C A M / K), \mathrm{R} \& \mathrm{D}$ intensity $\left(R \& D_{l a g}\right)$, and the broad and narrow outsourcing measures $\left(O S^{\text {narr }}\right.$ and $\left.O S^{\text {broad }}-O S^{\text {narr }}\right)$. 
Table 6: Robustness analysis - I. Dependent variable is $h$.

\begin{tabular}{|c|c|c|c|c|c|c|}
\hline \multirow[t]{3}{*}{ Input skill measure } & \multicolumn{2}{|c|}{$\sigma$} & \multirow{2}{*}{$\frac{\sigma^{w}}{(3)^{\ddagger}}$} & \multicolumn{3}{|c|}{$\sigma^{2 \mathrm{~d}}$} \\
\hline & (1) & (2) & & (4) & (5) & (6) \\
\hline & $\begin{array}{l}5 \text {-year } \\
\text { changes }\end{array}$ & $\begin{array}{l}\text { Additional } \\
\text { Controls }\end{array}$ & $\begin{array}{l}\text { Wage } \\
\text { bill }\end{array}$ & $\begin{array}{l}1967 \\
\text { only }\end{array}$ & $\begin{array}{l}1992 \\
\text { only }\end{array}$ & $\begin{array}{l}2002 \\
\text { only }\end{array}$ \\
\hline Input skill intensity: $\sigma / \sigma^{2 \mathrm{~d}} / \sigma^{w}$ & $\begin{array}{l}.609 * * * \\
(.108)\end{array}$ & $\begin{array}{l}.579 * * * \\
(.142)\end{array}$ & $\begin{array}{l}.535^{* * * *} \\
(.177)\end{array}$ & $\begin{array}{l}.513 * * \\
(.260)\end{array}$ & $\begin{array}{l}.492 * * * \\
(.123)\end{array}$ & $\begin{array}{l}.488 * * * \\
(.169)\end{array}$ \\
\hline Equipment per worker: $k^{\text {equip }}$ & $\begin{array}{l}-.0412 \\
(.033)\end{array}$ & $\begin{array}{l}-.0973^{*} \\
(.055)\end{array}$ & $\begin{array}{l}-.176 * * * \\
(.064)\end{array}$ & $\begin{array}{l}.15 \\
(.345)\end{array}$ & $\begin{array}{l}.073 \\
(.114)\end{array}$ & $\begin{array}{l}-.0261 \\
(.087)\end{array}$ \\
\hline Office equipment: $O C A M / K$ & $\begin{array}{l}.057 \\
(.112)\end{array}$ & $\begin{array}{l}.228 \\
(.184)\end{array}$ & $\begin{array}{l}0.125 \\
(.242)\end{array}$ & $\begin{array}{l}3.714 * * * \\
(1.253)\end{array}$ & $\begin{array}{l}4.376 * * * \\
(.513)\end{array}$ & $\begin{array}{l}.950 * \\
(.490)\end{array}$ \\
\hline $\begin{array}{l}\text { High-Tech capital: difference } \\
\qquad(H T / K-O C A M / K)\end{array}$ & $\begin{array}{l}.0778 \\
(.092)\end{array}$ & $\begin{array}{l}.459 * * \\
(.182)\end{array}$ & $\begin{array}{l}.554 * * \\
(.242)\end{array}$ & $\begin{array}{l}3.829 * * * \\
(.931)\end{array}$ & $\begin{array}{l}2.206 * * * \\
(.518)\end{array}$ & $\begin{array}{l}2.962 * * * \\
(.689)\end{array}$ \\
\hline R\&D intensity $R \& D_{l a g}$ & $\begin{array}{l}.172 * * \\
(.070)\end{array}$ & $\begin{array}{l}.419 * * \\
(.178)\end{array}$ & $\begin{array}{l}.440 * * \\
(.187)\end{array}$ & $\begin{array}{l}1.817^{*} \\
(1.058)\end{array}$ & $\begin{array}{l}-.13 \\
(.360)\end{array}$ & $\begin{array}{l}.655^{*} \\
(.340)\end{array}$ \\
\hline $\begin{array}{l}\text { Outsourcing: } O S^{\text {narr }} \\
\quad \text { (narrow) }\end{array}$ & $\begin{array}{l}.0568^{* * *} \\
(.026)\end{array}$ & $\begin{array}{l}.132 * * * \\
(.045)\end{array}$ & $\begin{array}{l}.111^{*} \\
(.061)\end{array}$ & $\begin{array}{l}-.558 * * \\
(.281)\end{array}$ & $\begin{array}{l}.0701 \\
(.099)\end{array}$ & $\begin{array}{l}.0493 \\
(.107)\end{array}$ \\
\hline $\begin{array}{l}\text { Outsourcing (broad): difference } \\
\left(O S^{\text {broad }}-O S^{\text {narr }}\right)\end{array}$ & $\begin{array}{l}.104 * * \\
(.042)\end{array}$ & $\begin{array}{l}.203 * * * \\
(.071)\end{array}$ & $\begin{array}{l}.186^{* *} \\
(.075)\end{array}$ & $\begin{array}{l}-.0332 \\
(.561)\end{array}$ & $\begin{array}{l}.0584 \\
(.126)\end{array}$ & $\begin{array}{l}.105 \\
(.145)\end{array}$ \\
\hline Many inputs: $I_{i}^{n_{i}>\bar{n}}$ & & $\begin{array}{l}.00257 \\
(.004)\end{array}$ & & $\begin{array}{l}.00722 \\
(.023)\end{array}$ & $\begin{array}{l}.0352^{* * * *} \\
(.013)\end{array}$ & $\begin{array}{l}.00291 \\
(.017)\end{array}$ \\
\hline Input variety: $\left(1-H_{i}\right)$ & & $\begin{array}{l}.00407 \\
(.016)\end{array}$ & & $\begin{array}{l}-.131 \\
(.090)\end{array}$ & $\begin{array}{l}.028 \\
(.037)\end{array}$ & $\begin{array}{l}-.00333 \\
(.056)\end{array}$ \\
\hline Relative wage: $\ln \left(w_{H} / w_{L}\right)$ & & $\begin{array}{l}-.0474 * * \\
(.020)\end{array}$ & & & & \\
\hline Real shipments: $\ln (Y)$ & & $\begin{array}{l}.00238 \\
(.005)\end{array}$ & & & & \\
\hline Productivity: $\ln (T F P)$ & & $\begin{array}{l}-.00585 \\
(.009)\end{array}$ & & & & \\
\hline Value added share & & $\begin{array}{l}.0344 \\
(.034)\end{array}$ & & & & \\
\hline Sector fixed effects & no & yes & yes & no & no & no \\
\hline Time fixed effects & yes & yes & yes & no & no & no \\
\hline $\begin{array}{l}\text { Adjusted } R^{2} \\
R^{2} \text { (within) }\end{array}$ & .23 & $\begin{array}{l}.96 \\
.51\end{array}$ & $\begin{array}{l}.96 \\
.52\end{array}$ & .27 & .71 & .66 \\
\hline Observations & 2,448 & 2,789 & 2,806 & 329 & 357 & 358 \\
\hline
\end{tabular}

$\ddagger$ The dependent variable in (3) is the non-production wage bill share: $h^{w} \equiv w_{H} H /\left(w_{H} H+w_{L} L\right)$.

Notes: Quinquennial data, 1967-2005 in columns (1)-(3). Robust standard errors in parentheses (for (1)-(3) clustered by sector). Key: $* * *$ significant at $1 \%$; * 5\%;*10\%. Regressions (1)-(3) are weighted by sectors' average share in manufacturing employment; (4)-(6) by the sector's employment in the respective years 1967, 1992, and 2002. All variables in (1) represent 5-year differences (in this case, $R \& D$ intensity is $R \& D_{t}-R \& D_{t-5}$.), while levels are used in the remaining regressions. 
Table 7: Robustness analysis - II. Dependent variable is $h$.

\begin{tabular}{lllllll}
\hline \hline Input skill measure & \multicolumn{3}{c}{ - Baseline: $\sigma_{i t}$} & \multicolumn{2}{c}{$\sigma_{i t}^{2 \mathrm{~d}}$} & \multicolumn{2}{c}{$\sigma_{i t}^{w}$} \\
& unweighted & $1967-92$ & \multicolumn{2}{c}{ Sector-specific time trends } \\
& $(1)$ & $(2)$ & $(3)$ & $(4)$ & $(5)^{\ddagger}$ \\
\hline Input skill intensity: $\sigma_{i t} / \sigma_{i t}^{2 \mathrm{~d}} / \sigma_{i t}^{w}$ & $.497 * * *$ & $.583^{* * *}$ & $.467 * * *$ & $.470^{* * *}$ & $.441^{* * *}$ \\
& $(.121)$ & $(.148)$ & $(.143)$ & $(.171)$ & $(.157)$ \\
Control variables & yes & yes & yes & yes & yes \\
Sector fixed effects & yes & yes & yes & yes & yes \\
Time fixed effects & yes & yes & yes & yes & yes \\
Adjusted $R^{2}$ & .923 & .973 & .985 & .985 & .980 \\
$R^{2}($ within) & .380 & .570 & .821 & .820 & .830 \\
Observations & 2,806 & 2,090 & 2,806 & 2,806 & 2,806 \\
\hline \hline
\end{tabular}

Notes: ${ }^{\ddagger}$ The dependent variable in (5) is the non-production wage bill share: $h^{w} \equiv w_{H} H /\left(w_{H} H+w_{L} L\right)$. Quinquennial data, 1967-2002, for 358 U.S. manufacturing sectors. Clustered standard errors (by sector) in parentheses. Key: *** significant at $1 \%$;* 5\%;*10\%. Regressions in columns $2-5$ are weighted by sectors' average share in manufacturing employment. Control variables include: Equipment per worker $\left(k^{\text {equip }}\right)$, office and computer capital $(O C A M / K)$, non-computing high-tech capital $(H T / K-O C A M / K)$, R\&D intensity $\left(R \& D_{\text {lag }}\right)$, and the broad and narrow outsourcing measures $\left(O S^{\text {narr }}\right.$ and $\left.O S^{\text {broad }}-O S^{\text {narr }}\right)$.

Table 8: Interaction of input skill intensity with input differentiation. Dependent variable is $h_{i t}$.

\begin{tabular}{|c|c|c|c|c|c|c|}
\hline \multirow{3}{*}{$\begin{array}{l}\text { Sample } \\
\text { Input skill measure }\end{array}$} & \multicolumn{3}{|c|}{$\ldots$ Full Sample —_ } & \multicolumn{3}{|c|}{$\longrightarrow$ Benchmark years -} \\
\hline & $\sigma_{i t}$ & $\sigma_{i t}$ & $\sigma_{i t}^{2 \mathrm{~d}}$ & $\sigma_{i t}$ & $\sigma_{i t}$ & $\sigma_{i t}^{2 \mathrm{~d}}$ \\
\hline & (1) & (2) & (3) & (4) & (5) & (6) \\
\hline $\begin{array}{l}\text { Input skill intensity }\left(\beta_{1}\right) \text { : } \\
\quad \sigma_{i t} / / \sigma_{i t}^{2 \mathrm{~d}}\end{array}$ & $\begin{array}{l}.0990 \\
(.217)\end{array}$ & $\begin{array}{l}.0504 \\
(.164)\end{array}$ & $\begin{array}{l}-.0249 \\
(.243)\end{array}$ & $\begin{array}{r}.0645 \\
(.199)\end{array}$ & $\begin{array}{r}.0808 \\
(.168)\end{array}$ & $\begin{array}{l}-.108 \\
(.242)\end{array}$ \\
\hline $\begin{array}{l}\text { Interaction w/ differentiation }\left(\beta_{2}\right) \text { : } \\
\sigma_{i t} \times \kappa_{i} / / \sigma_{i t}^{2 \mathrm{~d}} \times \kappa_{i}\end{array}$ & $\begin{array}{l}1.800 * * * \\
(.374)\end{array}$ & $\begin{array}{l}1.303 * * * \\
(.310)\end{array}$ & $\begin{array}{l}1.254 * * * \\
(.458)\end{array}$ & $\begin{array}{l}1.649 * * * \\
(.363)\end{array}$ & $\begin{array}{l}1.080 * * * \\
(.357)\end{array}$ & $\begin{array}{l}0.977 * * \\
(.453)\end{array}$ \\
\hline Implied coefficient: $\hat{\beta}=\hat{\beta}_{1}+\hat{\beta}_{2} \bar{\kappa}$ & $1.084 * * *$ & $.763 * * *$ & $.661 * * *$ & $.967 * * *$ & $.672 * * *$ & $.426 * * *$ \\
\hline Controls & no & yes & yes & no & yes & yes \\
\hline Sector fixed effects & yes & yes & yes & yes & yes & yes \\
\hline Time fixed effects & yes & yes & yes & yes & yes & yes \\
\hline Adjusted $R^{2}$ & .954 & .956 & .958 & .961 & .965 & 964 \\
\hline$R^{2}$ (within) & .426 & .490 & 469 & .468 & .528 & .511 \\
\hline Observations & 17,184 & 16,633 & 16,633 & 2,864 & 2,806 & 2,806 \\
\hline
\end{tabular}

Notes: Quinquennial data, 1967-2002 in columns 1 and 2; annual data, 1958-2005, in columns 3-5. Clustered standard errors (by sector) in parentheses. Key: *** significant at 1\%;** 5\%;* 10\%. All regressions and the mean $\bar{\kappa}$ are weighted by sectors' average share in total manufacturing employment. Controls variables include: Equipment per worker ( $\left.k^{\text {equip }}\right)$, office and computer capital $(O C A M / K)$, non-computing high-tech capital $(H T / K-O C A M / K)$, R\&D intensity $\left(R \& D_{\text {lag }}\right)$, and the broad and narrow outsourcing measures $\left(O S^{\text {narr }}\right.$ and $\left.O S^{\text {broad }}-O S^{\text {narr }}\right)$, as well as their interactions with input differentiation: $k^{\text {equip }} \times \kappa_{i}, O C A M / K \times \kappa_{i},(H T / K-O C A M / K) \times \kappa_{i}, R \& D_{\text {lag }} \times \kappa_{i}, O S^{\text {narr }} \times \kappa_{i}$, and $\left(O S^{\text {broad }}-O S^{\text {narr }}\right) \times \kappa_{i}$. Weighted average input differentiation is $\bar{\kappa}=.547$. 
Table 9: Estimating the size of ITSC. Dependent variable is $\ln \left(H_{i t} / L_{i t}\right)$

\begin{tabular}{|c|c|c|c|c|c|c|}
\hline Measure for input skill bias & $\begin{array}{l}\sigma_{i t}^{A} \\
(1)\end{array}$ & $\begin{array}{l}\sigma_{i t}^{A} \\
(2)\end{array}$ & $\begin{array}{l}\sigma_{i t}^{A} \\
(3)\end{array}$ & $\begin{array}{l}\sigma_{i t}^{A} \\
(4)\end{array}$ & $\begin{array}{c}\sigma_{i t}^{A, 2 \mathrm{~d}} \\
(5)\end{array}$ & $\begin{array}{c}\sigma_{i t}^{A, 2 \mathrm{~d}} \\
(6)\end{array}$ \\
\hline \multicolumn{7}{|c|}{ PANEL A: Full Sample } \\
\hline Input skill bias & $\begin{array}{l}.684 * * * \\
(.057)\end{array}$ & $\begin{array}{l}.327 * * * \\
(.053)\end{array}$ & $\begin{array}{l}.223 * * * \\
(.048)\end{array}$ & $\begin{array}{l}.106 * * * \\
(.036)\end{array}$ & $\begin{array}{l}.135^{* *} \\
(.058)\end{array}$ & $\begin{array}{l}.0867 * \\
(.046)\end{array}$ \\
\hline \multicolumn{7}{|l|}{ [controls and FE listed below] } \\
\hline $\begin{array}{l}R^{2} \\
R^{2} \text { (within) } \\
\text { Observations }\end{array}$ & $\begin{array}{l}.428 \\
- \\
17,184 \\
\end{array}$ & $\begin{array}{l}.946 \\
.390 \\
17,184 \\
\end{array}$ & $\begin{array}{l}.950 \\
.432 \\
16,633 \\
\end{array}$ & $\begin{array}{l}.966 \\
.736 \\
16,633 \\
\end{array}$ & $\begin{array}{l}.949 \\
.417 \\
16,633 \\
\end{array}$ & $\begin{array}{l}.977 \\
.735 \\
16,633 \\
\end{array}$ \\
\hline \multicolumn{7}{|c|}{ PANEL B: Benchmark years } \\
\hline Input skill bias & $\begin{array}{l}.709 * * * \\
(.060)\end{array}$ & $\begin{array}{l}.268 * * * \\
(.072)\end{array}$ & $\begin{array}{l}.149 * * \\
(.071)\end{array}$ & $\begin{array}{r}.0774 \\
(.079)\end{array}$ & $\begin{array}{l}.124 \\
(.084)\end{array}$ & $\begin{array}{l}.161 * * \\
(.081)\end{array}$ \\
\hline \multicolumn{7}{|l|}{ [controls and FE listed below] } \\
\hline $\begin{array}{l}R^{2} \\
R^{2} \text { (within) } \\
\text { Observations } \\
\end{array}$ & $\begin{array}{l}.449 \\
- \\
2,864 \\
\end{array}$ & $\begin{array}{l}.959 \\
.421 \\
2,864 \\
\end{array}$ & $\begin{array}{l}.957 \\
.469 \\
2,806 \\
\end{array}$ & $\begin{array}{l}.987 \\
.819 \\
2,806 \\
\end{array}$ & $\begin{array}{l}.957 \\
.465 \\
2,806 \\
\end{array}$ & $\begin{array}{l}.988 \\
.821 \\
2,806 \\
\end{array}$ \\
\hline \multicolumn{7}{|c|}{ Controls and FE - used in both panels } \\
\hline $\begin{array}{l}\text { Control variables } \\
\text { Sector fixed effects } \\
\text { Time fixed effects } \\
\text { Sector time trends }\end{array}$ & $\begin{array}{l}\text { no } \\
\text { no } \\
\text { no } \\
\text { no }\end{array}$ & $\begin{array}{l}\text { no } \\
\text { yes } \\
\text { yes } \\
\text { no }\end{array}$ & $\begin{array}{l}\text { yes } \\
\text { yes } \\
\text { yes } \\
\text { no }\end{array}$ & $\begin{array}{l}\text { yes } \\
\text { yes } \\
\text { yes } \\
\text { yes }\end{array}$ & $\begin{array}{l}\text { yes } \\
\text { yes } \\
\text { yes } \\
\text { no }\end{array}$ & $\begin{array}{l}\text { yes } \\
\text { yes } \\
\text { yes } \\
\text { yes }\end{array}$ \\
\hline
\end{tabular}

Notes: Annual data, 1958-2005, in panel A; quinquennial data, 1967-2002 in panel B. Clustered standard errors (by sector) in parentheses. Key: *** significant at 1\%;**5\%;*10\%. All regressions are weighted by sectors' average share in total manufacturing employment. Input skill bias $\sigma_{i t}^{A}$ and $\sigma_{i t}^{A, 2 \mathrm{~d}}$ are calculated as explained in section 3.5. Control variables include: Equipment per worker $\left(k^{\text {equip }}\right)$, office and computer capital $(O C A M / K)$, non-computing high-tech capital $(H T / K-O C A M / K), \mathrm{R} \& \mathrm{D}$ intensity $\left(R \& D_{l a g}\right)$, and the broad and narrow outsourcing measures $\left(O S^{\text {narr }}\right.$ and $\left.O S^{\text {broad }}-O S^{\text {narr }}\right)$. 